Meta

Journal des traducteurs

Translators' Journal

\title{
Revisiting the Translator's Visibility: Does Visibility Bring Rewards?
}

\section{Fung-Ming Christy Liu}

Volume 58, numéro 1, avril 2013

URI : https://id.erudit.org/iderudit/1023808ar

DOI : https://doi.org/10.7202/1023808ar

Aller au sommaire du numéro

\section{Éditeur(s)}

Les Presses de l’Université de Montréal

ISSN

0026-0452 (imprimé)

1492-1421 (numérique)

Découvrir la revue

Citer cet article

Liu, F.-M. C. (2013). Revisiting the Translator's Visibility: Does Visibility Bring Rewards? Meta, 58(1), 25-57. https://doi.org/10.7202/1023808ar
Résumé de l'article

Le rôle et la visibilité du traducteur font l'objet d'un intérêt renouvelé. Certains traductologues ont mobilisé les concepts théoriques de champ, d'habitus et de capital du sociologue français Pierre Bourdieu pour effectuer des recherches empiriques visant à comprendre comment les traducteurs ou les interprètes perçoivent leur rôle et le type de capital auquel ils aspirent. Le présent article fait état de résultats obtenus dans le cadre d'une étude associant des approches quantitatives et qualitatives pour cerner le plus possible la visibilité des traducteurs, entendue comme la capacité de communiquer directement avec les clients et/ou les utilisateurs finaux. Ce texte rend compte de l'analyse quantitative de la relation entre la visibilité du traducteur et le capital qu'ils affirment obtenir. L'analyse a été effectuée auprès de 193 traducteurs chinois en Chine, à Hong Kong, Taiwan et Macau. Les résultats indiquent que la visibilité est valorisante en termes d'échanges sociaux et d'expériences d'apprentissage, mais pas en termes de rémunération ni de prestige. En outre, l'analyse montre que certaines variables sociales telles que le sexe, le niveau d'études, le domicile, la spécialisation et l'expérience professionnelle du traducteur ne sont pas liées à la visibilité ni au capital accumulé, tandis que l'apparition du nom de traducteur sur les traductions est en rapport très étroit avec le capital reçu.
Ce document est protégé par la loi sur le droit d'auteur. L'utilisation des services d'Érudit (y compris la reproduction) est assujettie à sa politique d'utilisation que vous pouvez consulter en ligne.

https://apropos.erudit.org/fr/usagers/politique-dutilisation/ 


\title{
Revisiting the Translator's Visibility: Does Visibility Bring Rewards?
}

\author{
FUNG-MING CHRISTY LI U \\ The Hong Kong Institute of Education, Hong Kong \\ liufm@ied.edu.hk
}

\begin{abstract}
RÉSUMÉ
Le rôle et la visibilité du traducteur font l'objet d'un intérêt renouvelé. Certains traductologues ont mobilisé les concepts théoriques de champ, d'habitus et de capital du sociologue français Pierre Bourdieu pour effectuer des recherches empiriques visant à comprendre comment les traducteurs ou les interprètes perçoivent leur rôle et le type de capital auquel ils aspirent. Le présent article fait état de résultats obtenus dans le cadre d'une étude associant des approches quantitatives et qualitatives pour cerner le plus possible la visibilité des traducteurs, entendue comme la capacité de communiquer directement avec les clients et/ou les utilisateurs finaux. Ce texte rend compte de l'analyse quantitative de la relation entre la visibilité du traducteur et le capital qu'ils affirment obtenir. L'analyse a été effectuée auprès de 193 traducteurs chinois en Chine, à Hong Kong, Taiwan et Macau. Les résultats indiquent que la visibilité est valorisante en termes d'échanges sociaux et d'expériences d'apprentissage, mais pas en termes de rémunération ni de prestige. En outre, l'analyse montre que certaines variables sociales telles que le sexe, le niveau d'études, le domicile, la spécialisation et l'expérience professionnelle du traducteur ne sont pas liées à la visibilité ni au capital accumulé, tandis que l'apparition du nom de traducteur sur les traductions est en rapport très étroit avec le capital reçu.
\end{abstract}

\section{ABSTRACT}

There has been a huge revival of interest in the role of translators and their visibility. Some Translation Studies scholars have mobilized French sociologist Pierre Bourdieu's theorical concepts of field, habitus and capital to carry out empirical research studies in an attempt to understand how translators or interpreters perceive their roles and what kind of capital they pursue. This article presents part of the findings from a large empirical study in which quantitative and qualitative approaches are combined in an attempt to carry out a thorough investigation of translators' visibility, understood as the capacity to communicate directly with clients and/or end-users. The present article reports on the quantitative analysis of the relationship between translator's visibility and the amount of capital that they say they receive. The analysis is based on 193 Chinese translators in China, Hong Kong, Taiwan and Macao. The findings suggest that visibility is rewarding in terms of social exchanges and learning experience, but not in terms of pay and prestige. In addition, the analysis shows that some social variables including sex, level of education, region that the translator lives in, the translator's major field of study and the time spent on translation are not related to visibility or capital received. Meanwhile, the appearance of the translator's name on translations is significantly related to the capital received.

\section{MOTS-CLÉS/KEYWORDS}

visibilité, capital symbolique, capital social, capital culturel, capital économique visibility, symbolic capital, social capital, cultural capital, economic capital 


\section{Introduction}

In the literature there are abundant references to the view that translators tend to be invisible and subservient (e.g., Hermans and Lambert 2006; Simeoni 1998; Wilss 1999; Bassnett 2002; Risku 2004; Sela-Sheffy 2006; Dam and Korning Zethsen 2008). Although there has been a huge revival of interest in the role of translators and their visibility, much of the discussion seems to focus on the translator's relation to the text (see Leech 2005; Dam and Korning Zethsen 2008). However, the present article places heavy emphasis on people, not texts, because we regard translators as important mediators during the translation process. In this article, as a working definition, the translator's visibility refers to situations in which translators can directly communicate with clients and end-users (details will be explained in Section 3.1). We concentrate on issues concerning whether or not the translator's mediating role is visible to their clients and end-users. We give particular attention to the relations between translators, clients and end-users because we believe, with Donald C. Kiraly, that the responsibility of today's translators "extends far beyond 'translation competence' or the ability to create an equivalent target text in one language on the basis of a pre-existing text written in another language" (Kiraly 2003: 13). Translators are also required to communicate effectively during the process of translation and thus they deserve our attention.

From November 3, 2009 to February 6, 2010, we conducted a questionnaire survey, in which both quantative and qualitative approaches are combined, to carry out a thorough investigation into translator's visibility, the amount of capital that translators say they receive, and their job-related happiness. The present article reports only on the quantitative analysis of the relationship between translator's visibility and the amount of capital that the translators say they receive. ${ }^{1}$ Models from social psychology are employed to empirically study the relationship between visibility and capital received.

\section{Research question, hypotheses and assumptions}

\subsection{Research question}

Our research question concerns the relationship between the translator's visibility and the amount of capital that the translators say they receive. We seek to find out whether visible translators receive more symbolic, economic, social and cultural capital than do invisible translators.

\subsection{Hypotheses}

Guided by the research question, we have constructed a main hypothesis for this study that we will refer to as $\mathrm{H}_{1}$ : The more visible the translators, the more capital they receive. To gain a complete understanding of the translator's visibility and the various kinds of capital these professionals say they receive, we also test the following lower-level hypotheses:

$\mathrm{H}_{1 \mathrm{a}}$ : The more visible the translators, the more symbolic capital they receive.

$\mathrm{H}_{1 \mathrm{~b}}$ : The more visible the translators, the more economic capital they receive.

$\mathrm{H}_{1 \mathrm{c}}$ : The more visible the translators, the more social capital they receive.

$\mathrm{H}_{1 \mathrm{~d}}$ : The more visible the translators, the more cultural capital they receive. 


\subsection{Assumptions}

In this study, we assume that the translator's work experience is a major factor affecting both the translator's visibility and the amount of capital that the translators say they receive. For example, the translator's visibility and the capital received may increase with more experience. Here we would like to highlight the point that work experience does not equal expertise in our study. As the focus of our study is on the visibility-capital relationship, the impact of the work-experience variable must be neutralized. Hence, we test our hypotheses with groups of translators having the same or similar experience distribution. We classify our subjects into three groups according to their years of work experience. The classification will be further explained in Section 5.1.2.

\section{Methodology}

In this section we operationalize the terms visibility and capital.

\subsection{Operationalizing visibility}

The translator's visibility has been a much discussed issue in Translation Studies since Lawrence Venuti used the term invisibility in his book The Translator's Invisibility (1995). Although we use the term visibility for this study, our focus is different from that adopted by Venuti (1995) as he discusses the in/visibility of the translator in the target text. We concentrate on issues concerning whether or not the translator's mediating role is visible to the client and the end-user. This investigation allows us to explicitly define visibility in terms of the workplace and formulate various modes of visibility between translators, clients and end-users (see Figure 1).

In Translation Studies, some scholars (Angelelli 2001, 2004; Dam and Korning Zethsen $2008 ; 2009)$ have empricially examined visibility in the workplace. Angelelli (2001; 2004) conducted an empricial study to examine interpreters' visibility and their perceptions of their role through a survey administered across languages in Canada, Mexico and the United States. She defines the visibility of the interpreter as "the manifestations of the interpreter's behaviors to manage social factors as the interpretation unfolds" (Angelelli 2001: 14). Her survey contained five components of visibility:
1) aligning with one of the parties;
2) establishing trust/facilitating mutual respect between the parties;
3) communicating affect as well as message;
4) explaining cultural gaps/interpreting culture;
5) establishing communication rules.

It should be noted that Angelelli studies interpreters and their perceptions of their role, whereas our present study focuses on translators. Our definition of translator includes people who do translation and/or interpreting as part of their jobs and are paid accordingly, either on a full-time, part-time or project basis. This does not include people who only handle oral renditions of spoken discourse from one language into another language. Dam and Korning Zethsen $(2008 ; 2009)$ carried out a questionnaire-based investigation of the status of Danish company translators. 
Visibility was one of the elements in their definition of the translator's status: "The concept of status and how to define it were considered in relation to four parameters of occupational status: 1) salary; 2) education/expertise; 3) visibility/fame; 4) power/ influence" (Dam and Korning Zethsen 2008: 71). These two authors operationalize visibility by asking about the physical position of translators in their companies, their professional contact with other company employees, their perception of the degree of visibility of their work in the company, and whether or not their names are known by their company's employees (Dam and Korning Zethsen 2008: 88-91). Our use of the concept of visibility is much closer to that of Dam and Korning Zethsen, although, they did not focus on the translator's actual interactions with the client and/ or the end-user.

As we have mentioned, our working definition of the translator's visibility is based on situations in which translators can directly communicate with clients and end-users. To say that a translator is visible means that their role goes beyond the linguistic level. This work environment allows translators to receive recognition, appreciation or criticism of their communicative roles and work. We would like to stress that this paper focuses on the translator-client relationship, not the translatoremployer relationship. In this study, a client is understood to be a company/ brand/ organization/ corporate institution paying for the translator's translations, while an employer means the translator's supervisor or the person who oversees the translator's translation assignments at work. In our survey, we make a very clear distinction between client and employer by asking two questions (see Appendix) in order to avoid confusion between the two terms.

Invisible translators are defined as those who never or seldom have the opportunity to communicate with their clients or end-users. Conversely, visible translators are those who can communicate with both their clients and end-users sometimes, often or very often.

In fact, visibility and invisibility are only two extreme ends of a spectrum. Visibility is not to be discussed in binary terms; it can be understood to stand in a continuum. Wendy Leech, who has used empirical methods to study the translator's visibility, reminds us that "there are different types of invisibility that concern a translator" (Leech 2005: 15). Guided by our working definitions, the visibility of the translator is classified into four categories that relate to the degree of direct communication between translators and their clients on the one hand, and with end-users on the other (Figure 1). We characterize the following translator-types:

1. The behind-the-scenes translator is invisible to clients and end-users. They never or seldom communicate with the latter two parties. For example, they may work on instruction manuals or they are employed by translation agencies to render texts that are corporate products.

2. The end-user-visible translator never or seldom communicates with the client but does interact with the end-user sometimes, often or very often. Examples are in-house translators who render administrative notices, or in-house corporate communications officers who are responsible for producing bilingual materials, such as newsletters, for their companies. They do not have to communicate with their clients, as most of the materials they translate are provided by their supervisors. However, they are always required to communicate with the end-user for purposes such as getting feedback on the work they have produced. 
3. The client-visible translator often or very often communicates with the client but they never or seldom interact with the end-user. This is often the case of translators who work on publications such as bilingual magazines, where they are required to communicate with the client to get clear instructions on aspects such as the format or style before they start to translate. However, they do not interact with target-text readers.

4. The visible translator sometimes, often or very often communicates with both the client and the end-user. In greater China, translators who translate press releases (Chinese-English) in public relations agencies can be classified as visible translators. Although translation is their daily duty, they basically are not designated as translators in the company. Their job titles vary according to the culture and business nature of the companies. Titles such as Account Executive, Communication Consultant, Corporate Communications Specialist, Marketing Communications Executive and Public Affairs Specialists are commonly found in the public relations industry. These people can get in touch directly with the client (a brand, a corporate company or an organization) and with end-users (mainly journalists, reporters or correspondents).

To summarize, Figure 1 diagrammatically presents the characteristics of each of the categories for the visibility of the translator.

FIGURE 1

Visibility-based translator types

\begin{tabular}{|l|l|l|}
\hline \multicolumn{2}{|c|}{ visible to end-users } & \\
\hline $\begin{array}{l}\text { end-user-visible } \\
\text { translators }\end{array}$ & visible translators & $\begin{array}{l}\text { visible } \\
\text { to } \\
\text { clients }\end{array}$ \\
\hline $\begin{array}{l}\text { behind-the-scenes } \\
\text { translators }\end{array}$ & $\begin{array}{l}\text { client-visible } \\
\text { translators }\end{array}$ & \\
\hline
\end{tabular}

\subsection{Operationalizing "capital"}

We briefly explain how we incorporate psychologist Peter Warr's job-related framework into Bourdieu's sociology in order to develop a construct for our study ${ }^{2}$.

\subsubsection{Bourdieu's concept of capital and Warr's job-related framework}

Bourdieu defines capital as "all the goods, material and symbolic, without distinction, that present themselves as rare and worthy of being sought after in a particular social formation" (Bourdieu 1977: 178). He identifies four major types of capital, including economic, social, symbolic and cultural capital. As this study examines the amount of capital that the translators say they receive, we are concerned that the abovementioned categories of capital probably do not have psychological reality for the subjects and thus they are inadequate for us to formulate survey questions. For example, most translators will not know what we mean if we ask about symbolic capital. Therefore, we incorporated Warr's framework in order to develop meaningful questions so that we can operationalize the concept of capital.

Warr (2007) has been studying happiness and unhappiness in the work settings. He has developed a framework of 12 key job determinants to examine why some people are happier than others. The 12 determinants are mediating factors associated with job-related happiness. According to Warr, a good job scores well across the 
12 determinants. Increases from low to moderate levels are likely to be associated with greater happiness, or conversely, their absence is likely to indicate unhappiness. The 12 determinants share at least a characteristic with the concept of capital: they are both worth being sought.

Table 1 shows the relationship between Bourdieu's theory of capital and the determinants derived from Warr's job-related framework. According to the table, there are four kinds of capital comprising 22 determinants. Here we would like to stress that a determinant is not equal to a capital, but a specific determinant may relate to a kind of capital depending on the questions asked.

TABLE 1

The relationship between Bourdieu's capital theory and Warr's job-related framework

\begin{tabular}{|c|c|}
\hline Bourdieu's capital & Determinants derived from Warr's framework \\
\hline \multirow[t]{8}{*}{ Symbolic capital } & Work independently \\
\hline & Decision-making opportunities at work \\
\hline & Fulfilling the expectation of the client \\
\hline & Fulfilling the expectation of the end-user \\
\hline & Professional respect \\
\hline & The company's reputation in the industry \\
\hline & The pride of the profession \\
\hline & The role of being a translation professional \\
\hline \multirow[t]{2}{*}{ Economic capital } & Salary \\
\hline & Long-term job security \\
\hline \multirow[t]{6}{*}{ Social capital } & A working environment that allows the person to strengthen the personal network \\
\hline & The client's appreciation of the person's translation work \\
\hline & The end-user's appreciation of the person's translation work \\
\hline & Moving between roles so that the person is not limited to doing translation only \\
\hline & Opportunity to work with people of the translation profession \\
\hline & Opportunity to work with people from different professions \\
\hline \multirow[t]{6}{*}{ Cultural capital } & Opportunity to learn new knowledge \\
\hline & Opportunity to improve translation skills \\
\hline & Opportunity to boost professional qualification \\
\hline & Opportunity to use the person's skills and expertise at work \\
\hline & Feedback on the person's translated work from the client \\
\hline & Feedback on the person's translated work from the end-user \\
\hline
\end{tabular}

\section{The questionnaire survey}

The first part of our questionnaire (see Appendix) collects data on the background information of the subjects and their visibility at work. After that, we collect data concerning the various kinds of capital that the subjects say they receive. The response categories are strongly disagree (SD), disagree (D), indifferent/ no opinion (I/NO), agree (A) and strongly agree (SA).

The subjects for this study are Chinese translators in the Greater China region, which comprises China (population over 1.3 billion), Hong Kong (population about seven million), Taiwan (population about 24 million) and Macao (population about 0.5 million). However, we are not able to determine the number of translators in Greater China. Also, we do not know the categories of the translation profession in 
Greater China and we cannot reach them equally, so this study does not use a random sampling method. Instead, non-probability convenience sampling (also known as accidental sampling) and snowball techniques are used. On November 3, 2009 we started to invite Chinese translators to participate in our questionnaire study. As the author has been in the media industry for ten years, relationships with publishers, media companies, public relations agencies and translation agencies in Greater China have been established. Email messages, together with the questionnaire as well as a cover letter were sent to the contacts to ask for their assistance in completing the questionnaire. In addition, subjects were located from the following Internet websites: ProZ.com ${ }^{3}$ (9,446 Chinese members doing English-Chinese translation as at March 12, 2010); TranslationDirectory. com $^{4}$ (598 members doing English to Chinese translation and 245 members doing Chinese to English translation); Ourtra.com ${ }^{5}$ (2,767 registered members) and Translators Database [譯者資料庫] ${ }^{6}$ (49 blogs), as well as Facebook ${ }^{7}$ (its social networking groups including Hong Kong PR Network, 1,245 members; Interpreti-traduttori-翻譯-interpreters-translator, 74 members; Are you a translator or interpreter? Join applied language solutions, 2,077 members; Chinese translation society, 83 members; Translator pride, 396 members and Taiwan translator \& interpreters, 73 members). After obtaining a subject's email address from the website, we sent an e-mail message to invite the recipient to fill out the questionnaire survey. After receiving the recipient's confirmation, we sent the questionnaire along with a cover letter to the person via email.

The decision to find samples from the above websites was made because these websites have a huge number of registered Chinese translators. This method of doing convenience sampling is one of the most effective ways of reaching the maximum number of target subjects within a short period of time. Some might consider that we might have a bias against non-Internet users. But the fact is that the Internet has become the translator's best friend nowadays (see Sofer 2006).

From November 3, 2009 to February 6, 2010, a total of 1,130 messages were sent out to invite the email receivers to take part in our questionnaire survey. In addition to the convenience sampling method, we also used snowball techniques. We asked the respondents to pass on an Internet link to as many other potential respondents as possible. By March 12, 2010, a total of 193 completed and valid questionnaires were returned.

\section{Results of the study}

Of the 193 translators who completed the questionnaire, 84 subjects (43.5\%) were male and 109 (56.5\%) were female, showing a relatively good representation of both sexes in our study, regardless of the convenience sampling and snowball techniques employed. More than one-third of the subjects (36.3\%) were between 25 and 29 years of age. The data show that 25 subjects (13.0\%) were from Hong Kong, 140 (72.5\%) were from mainland China, 27 (14.0\%) were from Taiwan and only one (0.5\%) subject was from Macao. Regarding the highest level of education received, 102 participants (52.9\%) reported undergraduate education, 71 subjects $(36.8 \%)$ reported some postgraduate education, of which 5 (2.6\%) reported completing a doctorate. Our subjects have translation experience ranging from 0.25 to 28 years, with a mean work experience of 5.94 years. Seventy subjects (36.3\%) have less than 3 years of 
experience, 69 (35.7\%) have three to seven years of experience, and 54 (28\%) have more than seven years of experience.

\subsection{Testing the hypotheses}

\subsubsection{Testing method}

Prior to testing our hypotheses, we need to understand the nature and pattern of our variables, so we can select the most appropriate testing method.

Our main hypothesis $\left(\mathrm{H}_{1}\right)$ - the more visible the translators, the more capital they receive - involves two continuous dependent variables: the translator's visibility and the capital received. In the first part of the questionnaire, we collected data concerning the translator's visibility by asking two questions:

1) Can you communicate directly with the client?

2) Are you able to get in touch with the end-user of your translation work?

The response categories were scored as follows: $0=$ never; $1=$ seldom; $2=$ sometimes; 3 = often; 4 = very often. To gain a rough index, the two scores were added together and mapped to the range of 0 to 1 for a score roughly representing the translator's visibility.

In the questionnaire, we collected data concerning the four kinds of capital received (including 22 determinants). The response categories were scored as follows: 0 = strongly disagree; 1 = disagree; 2 = indifferent/ no opinion; 3 = agree; and $4=$ strongly agree.

A Kolmogorov-Smirnov test was used to determine the normality of the two continuous dependent variables, in order to decide the situations in which the use of parametric or non-parametric tests may be appropriate. The results showed that, in our sample, the translator's visibility was not normally distributed $(\mathrm{p}=0.002)$, while the distribution of the capital received by our respondents was normal in shape $(\mathrm{p}=0.087)$. Thus, the translator's visibility index did not match the necessary prerequisite for the use of parametric tests, and so non-parametric tests were employed for the first main hypothesis.

For the four lower-level hypotheses $\left(\mathrm{H}_{1 \mathrm{a}}, \mathrm{H}_{1 \mathrm{~b}}, \mathrm{H}_{1 \mathrm{c}}, \mathrm{H}_{1 \mathrm{~d}}\right)$, which posit positive relationships between visibility and the amount of symbolic, economic, social and cultural capital received by our subjects, a Kolmogorov-Smirnov test was again used to determine the normality of these continuous variables. Since we knew that visibility was not normally distributed, we focused on the distribution of symbolic, economic, social and cultural capital received. The results showed that, in our sample, the amounts of symbolic capital $(\mathrm{p}=0.003)$, economic capital $(\mathrm{p}=0.004)$ and social capital ( $\mathrm{p}=0.002)$ received by our subjects were not normally distributed. However, the distribution of the amount of cultural capital $(\mathrm{p}=0.062)$ received was normal in shape. Further, none of the 22 determinants (variables) related to the four kinds of capital were normally distributed ( $p<0.001$ for all determinants). The tests thus indicated that we should use non-parametric tests to handle the four lower-level hypotheses, although parametric tests could be used for fine-grained analysis of cultural capital in the absence of visibility. 


\subsection{2. $H_{1}$ - The more visible the translator, the more capital they receive}

As we have mentioned earlier, the translator's work experience may be a factor influencing the translator's visibility and the amount of capital received; thus, the impact of the work experience must be neutralized when testing the hypothesis. Therefore, we tested our main hypothesis by grouping translators with the same or similar level of experience. We classified our subjects into three groups according to their years of work experience (Table 2).

Since we have the amount translators say they receive on each determinant of capital (total: 22 determinants), we can calculate the average amount of capital received, and test to see if this is positively correlated with the translator's visibility.

Table 2 also shows how important it is to neutralize the work experience factor if we want to examine the visibility-capital relationship, because the translator's visibility (mean) and capital received by the translators at work (mean and median) rise slightly with more experience.

TABLE 2

Type of translator by years of work experience

\begin{tabular}{|l|c|c|c|c|c|c|}
\hline \multirow{2}{*}{ Translator type } & \multirow{2}{*}{$\begin{array}{c}\text { Years of work } \\
\text { experience }\end{array}$} & \multirow{2}{*}{$\begin{array}{c}\text { Number of } \\
\text { subjects }\end{array}$} & \multicolumn{2}{|c|}{ Translator's visibility } & \multicolumn{2}{c|}{ Capital received } \\
\cline { 4 - 7 } & $\leq 3$ & 70 & 0.3679 & 0.3750 & 2.4727 & 2.4773 \\
\hline Novice & $>3, \leq 7$ & 69 & 0.3986 & 0.3750 & 2.5876 & 2.6818 \\
\hline Experienced & $>7$ & 54 & 0.4074 & 0.3750 & 2.6810 & 2.6818 \\
\hline Senior Experienced & - & 193 & 0.3899 & 0.3750 & 2.5721 & 2.6364 \\
\hline Total & - &
\end{tabular}

Using SPSS, we retrieved the Spearman's rho correlation between the translator's visibility (not normally distributed) and the average amount of capital received (normally distributed). A one-tailed test was performed, since a positive relationship between the variables was expected. Table 3 shows that the correlation between the translator's visibility and the average amount of the capital received is strong (correlation coefficient $=0.321)$, with an extremely high level of significance $(p<0.001)$. When we tested the hypothesis on the groups of translators with the same or similar level of work experience, the correlations are moderate to strong with high levels of significance. The correlation coefficients between the translator's visibility and the capital received by the novice, experienced and senior experienced translators are 0.245 (moderate), 0.285 (moderate) and 0.451 (strong), with $\mathrm{p}=0.021,0.009$ and $<0.001$ respectively.

\section{TABLE 3}

Spearman's rho correlation tests between the translator's visibility and the average amount of capital received

\begin{tabular}{|l|c|c|c|c|}
\hline \multirow{2}{*}{} & \multicolumn{4}{|c|}{ Translator's visibility } \\
\cline { 2 - 5 } & All & Novice & Experienced & Senior experienced \\
\hline Spearman's rho correlation & 0.321 & 0.245 & 0.285 & 0.451 \\
\hline p-value & $<0.001$ & 0.021 & 0.009 & $<0.001$ \\
\hline Mean capital $^{\star}$ & 2.5721 & 2.4727 & 2.5876 & 2.6810 \\
\hline Mean visibility $^{*}$ & 0.3899 & 0.3679 & 0.3986 & 0.4074 \\
\hline
\end{tabular}

* For reference only (non-parametric tests do not rely on the distribution parameters, e.g., mean). 
We can conclude that, in our sample, the hypothesis that the more visible the translators the more capital they receive is confirmed in a statistically significant way. This hypothesis holds even when the work experience factor is neutralized.

We have confirmed that the more visible translator receives more capital. However, as emphasized earlier, visibility and invisibility are only two poles, and there are different types of visibility that concern a translator. We have classified translators into four categories based on the extent of their direct communication with their clients and end-users (as explained in Section 3.1):

1) the behind-the-scenes translator, who never or seldom communicates with clients and end-users ( 65 respondents);

2) the client-visible translator, who never or seldom communicates with end-users but sometimes, often or very often communicates with clients (58 respondents);

3) the end-user-visible translator, who sometimes, often or very often communicates with end-users but never or seldom communicates with clients (16 respondents);

4) the visible translator, who sometimes, often or very often communicates directly with clients and end-users (54 respondents).

We performed an ANOVA test to investigate the differences in the average amount of capital received (normally distributed) by the four visibility-based translator types. The result indicates statistically significant differences between the average scores for the four types of translators $(p<0.001)$. The descriptive statistics are listed in Table 4. According to the mean and median values, the visible translator received the greatest amount of capital, followed by the end-user-visible translator, the client-visible translator and the behind-the-scenes translator.

TABLE 4

Descriptive statistics - the average amount of capital received across the four visibility-based translator types

\begin{tabular}{|l|c|c|c|c|c|}
\hline & $\mathrm{N}$ & $\begin{array}{c}\text { Mean capital } \\
\text { received }\end{array}$ & $\begin{array}{c}\text { Median capital } \\
\text { received }\end{array}$ & $\begin{array}{c}\text { Minimum capital } \\
\text { received }\end{array}$ & $\begin{array}{c}\text { Maximum capital } \\
\text { received }\end{array}$ \\
\hline Behind-the-scenes & 65 & 2.4098 & 2.4091 & 1.4091 & 3.1364 \\
\hline Client-visible & 58 & 2.5392 & 2.6136 & 1.7273 & 3.2273 \\
\hline End-user-visible & 16 & 2.7074 & 2.6591 & 2.2727 & 3.4091 \\
\hline Visible & 54 & 2.7626 & 2.7727 & 1.4545 & 3.7273 \\
\hline Total & $\mathbf{1 9 3}$ & $\mathbf{2 . 5 7 2 1}$ & $\mathbf{2 . 6 3 6 4}$ & $\mathbf{1 . 4 0 9 1}$ & $\mathbf{3 . 7 2 7 3}$ \\
\hline
\end{tabular}

Table 5 shows the results of the Scheffe post-hoc tests. The difference between the behind-the-scenes and the visible translators is significant $(p<0.001)$, as is the difference between the client-visible and the visible translators $(\mathrm{p}=0.031)$. These results imply that the visible translator receives more capital than the behind-thescenes and the client-visible translators to a statistically significant extent. While the visible translator also receives more capital than the end-user-visible translator on average, the difference is not statistically significant. 
TABLE 5

Scheffe post-hoc tests for ANOVA - Multiple comparisons of capital received across the four visibility-based translator types

\begin{tabular}{|l|l|c|c|c|}
\hline Translator type (I) & Translator type (J) & Mean difference (I-J) & p-value & $<\mathbf{0 . 0 5} ?$ \\
\hline Behind-the-scenes & Client-visible & -0.1294 & 0.345 & No \\
\hline Behind-the-scenes & End-user-visible & -0.2976 & 0.064 & No \\
\hline Behind-the-scenes & Visible & -0.3528 & $<0.001$ & Yes \\
\hline Client-visible & End-user-visible & -0.1682 & 0.512 & No \\
\hline Client-visible & Visible & -0.2234 & 0.031 & Yes \\
\hline End-user-visible & Visible & -0.0552 & 0.970 & No \\
\hline
\end{tabular}

The post-hoc tests cannot allow us to confirm, in a statistically significant way, that the visible translator receives more capital than the end-user-visible translator. To try and answer this, we tested the four lower-level hypotheses that examine the relationship between the translator's visibility and the four kinds of capital received. These four lower-level hypotheses are:

$\mathrm{H}_{\mathrm{a}}$ : The more visible the translator, the more symbolic capital they receive.

$\mathrm{H}_{\mathrm{b}}$ : The more visible the translator, the more economic capital they receive.

$\mathrm{H}_{\mathrm{lc}}$ : The more visible the translator, the more social capital they receive.

$\mathrm{H}_{\mathrm{ld}}$ : The more visible the translator, the more cultural capital they receive.

As done for our main hypothesis $\left(\mathrm{H}_{1}\right)$, we extracted the average amount of symbolic capital (8 determinants), economic capital (2 determinants), social capital (6 determinants) and cultural capital (6 determinants) the translators said they received. Using SPSS, the Spearman's rho correlation between the translator's visibility and the four kinds of capital received was retrieved. A one-tailed test was performed for each of the lower-level hypotheses, since a positive relationship between the variables was expected. The results are discussed below.

\subsection{3. $H_{1 a}$ - The more visible the translators, the more symbolic capital they receive}

The results of Spearman's rho correlation test, given in Table 6, show a weak correlation between the translator's visibility (not normally distributed) and the average amount of symbolic capital received (not normally distributed) (correlation coefficient $=0.173)$, with a high level of significance $(p=0.008)$. Only the correlation between the translator's visibility and the symbolic capital received by the senior experienced translators is strong (correlation coefficient $=0.370$ ), with a high level of significance $(p=0.003)$. As the results we obtained are not coherent, our first lowerlevel hypothesis, that the more visible translators receive more symbolic capital, can only be confirmed for the senior experienced translators. This means that only the more visible senior experienced translators enjoy more prestige and a higher status. 
TABLE 6

Spearman's rho correlation tests between the translator's visibility and the average amount of symbolic capital received

\begin{tabular}{|c|c|c|c|c|}
\hline & \multicolumn{4}{|c|}{ Translator's visibility } \\
\hline & All & Novice & Experienced & Senior experienced \\
\hline Spearman's rho correlation & 0.173 & 0.014 & 0.103 & 0.370 \\
\hline p-value & 0.008 & 0.453 & 0.199 & 0.003 \\
\hline Mean symbolic capital ${ }^{*}$ & 2.7740 & 2.6339 & 2.7935 & 2.9306 \\
\hline Mean visibility ${ }^{\star}$ & 0.3899 & 0.3679 & 0.3986 & 0.4074 \\
\hline
\end{tabular}

* For reference only (non-parametric tests do not rely on the distribution parameters, e.g., mean).

A positive correlation was expected between the translator's visibility and the symbolic capital received, but this can only be confirmed for the senior experienced translators. In order to explain this result, we performed eight Spearman's rho correlation tests (one-tailed) to look at the actual determinants (not normally distributed). Table 7 shows that the more visible senior experienced translators have more opportunity to make decisions at work (correlation coefficient $=0.345, \mathrm{p}=0.005$ ); better fulfill the end-user's expectations (correlation coefficient $=0.313, \mathrm{p}=0.011$ ); are more proud to be a part of the company (correlation coefficient $=0.252, \mathrm{p}=0.033$ ); and have a better recognized role as a translator (correlation coefficient $=0.242$, $\mathrm{p}=0.039$ ). These results imply that the more visible senior experienced translators enjoy more prestige and a higher status.

The results in Table 7 also show that the novice and experienced translators do not benefit much from visibility in terms of the amount of symbolic capital received. For the novice translators, there are negative relationships between their visibility and their opportunity to work independently (correlation coefficient $=-0.170$ ), and the recognition of their role as a translator (correlation coefficient $=-0.049$ ). Although the results for these determinants are not significant $(p>0.05)$, they still suggest that the more visible novice translators may have less opportunity to work independently, and may feel that their translator's role is unrecognized.

For the experienced translators, there are negative relationships between their visibility and their opportunity to work independently (correlation coefficient = $-0.139, \mathrm{p}=0.128$ ) and their performance in fulfilling client expectations (correlation coefficient $=-0.099, \mathrm{p}=0.210$ ). Again, although these results are not statistically significant, they still suggest that the more visible experienced translators may have less opportunity to work independently or to properly fulfill the expectation of their clients. Having said that, the more visible the experienced translators, the more professional respect they obtain (correlation coefficient $=0.218, \mathrm{p}=0.036$ ). 
TABLE 7

Spearman's rho correlation tests between the translator's visibility and the determinants of symbolic capital received

\begin{tabular}{|c|c|c|c|c|c|}
\hline & & All & Novice & Experienced & $\begin{array}{c}\text { Senior } \\
\text { Experienced }\end{array}$ \\
\hline \multirow{3}{*}{ Work independently } & Mean $^{*}$ & 3.2124 & 3.0714 & 3.2609 & 3.3333 \\
\hline & Correlation Coefficient & -0.041 & -0.170 & -0.139 & 0.149 \\
\hline & p-value (1-tailed) & 0.287 & 0.079 & 0.128 & 0.142 \\
\hline \multirow{3}{*}{$\begin{array}{l}\text { Decision-making } \\
\text { opportunities at work }\end{array}$} & Mean $^{*}$ & 2.5596 & 2.3714 & 2.5507 & 2.8148 \\
\hline & Correlation Coefficient & 0.178 & 0.042 & 0.150 & 0.345 \\
\hline & p-value (1-tailed) & 0.007 & 0.364 & 0.109 & 0.005 \\
\hline \multirow{3}{*}{$\begin{array}{l}\text { Fulfilling client } \\
\text { expectations }\end{array}$} & Mean $^{*}$ & 2.8187 & 2.7286 & 2.7681 & 3.0000 \\
\hline & \begin{tabular}{|l|} 
Correlation Coefficient \\
\end{tabular} & 0.022 & 0.048 & -0.099 & 0.104 \\
\hline & p-value (1-tailed) & 0.379 & 0.345 & 0.210 & 0.228 \\
\hline \multirow{3}{*}{$\begin{array}{l}\text { Fulfilling end-user } \\
\text { expectations }\end{array}$} & Mean $^{*}$ & 2.6684 & 2.5286 & 2.6667 & 2.8519 \\
\hline & Correlation Coefficient & 0.151 & 0.120 & 0.026 & 0.313 \\
\hline & p-value (1-tailed) & 0.018 & 0.161 & 0.415 & 0.011 \\
\hline \multirow{3}{*}{ Professional respect } & Mean $^{*}$ & 2.8031 & 2.6000 & 2.8406 & 3.0185 \\
\hline & \begin{tabular}{|l|} 
Correlation Coefficient \\
\end{tabular} & 0.127 & 0.010 & 0.218 & 0.130 \\
\hline & p-value (1-tailed) & 0.039 & 0.468 & 0.036 & 0.174 \\
\hline \multirow{3}{*}{$\begin{array}{l}\text { The company's } \\
\text { reputation in the } \\
\text { industry }\end{array}$} & Mean $^{*}$ & 2.4249 & 2.4000 & 2.3768 & 2.5185 \\
\hline & Correlation Coefficient & 0.140 & 0.029 & 0.198 & 0.252 \\
\hline & p-value (1-tailed) & 0.026 & 0.405 & 0.051 & 0.033 \\
\hline \multirow{3}{*}{$\begin{array}{l}\text { The pride of the } \\
\text { profession }\end{array}$} & Mean ${ }^{*}$ & 2.9171 & 2.8429 & 2.9855 & 2.9259 \\
\hline & Correlation Coefficient & 0.034 & 0.001 & 0.098 & 0.019 \\
\hline & p-value (1-tailed) & 0.317 & 0.495 & 0.212 & 0.447 \\
\hline \multirow{3}{*}{$\begin{array}{l}\text { The role of being a } \\
\text { translation professional }\end{array}$} & $\operatorname{Mean}^{*}$ & 2.7876 & 2.5286 & 2.8986 & 2.9815 \\
\hline & Correlation Coefficient & 0.073 & -0.049 & 0.064 & 0.242 \\
\hline & p-value (1-tailed) & 0.158 & 0.344 & 0.300 & 0.039 \\
\hline
\end{tabular}

* For reference only (non-parametric tests do not rely on the distribution parameters, e.g., mean).

In order to have a thorough understanding of the relationship between visibility and symbolic capital, we examined the differences in the amount of symbolic capital (not normally distributed) received by the four visibility-based translator types. The result of the Kruskal-Wallis test indicates statistically significant differences $(\mathrm{p}=0.038)$. The descriptive statistics are given in Table 8 . On the other hand, post-hoc tests (Table 9) show no statistically significant difference between the four types of translators. However, Table 8 still suggests that the end-user-visible translator, by mean rank, receives the greatest amount of symbolic capital, followed by the visible translator, the client-visible translator, and finally the behind-the-scenes translator. 
TABLE 8

Descriptive statistics - the average amount of symbolic capital received across the four visibility-based translator types

\begin{tabular}{|l|c|c|c|c|}
\hline & $\mathbf{N}$ & $\begin{array}{c}\text { Mean symbolic } \\
\text { capital received }^{*}\end{array}$ & $\begin{array}{c}\text { Median symbolic } \\
\text { capital received }\end{array}$ & $\begin{array}{c}\text { Mean rank for symbolic } \\
\text { capital received }\end{array}$ \\
\hline Behind-the-scenes & 65 & 2.6596 & 2.7500 & 81.21 \\
\hline Client-visible & 58 & 2.8103 & 2.8750 & 101.19 \\
\hline End-user-visible & 16 & 2.8984 & 2.9375 & 109.44 \\
\hline Visible & 54 & 2.8356 & 3.0000 & 107.82 \\
\hline Total & 193 & 2.7740 & 2.8750 & - \\
\hline
\end{tabular}

* For reference only (non-parametric tests do not rely on the distribution parameters, e.g., mean).

TABLE 9

Post-hoc tests for Kruskal-Wallis test - Mann-Whitney U tests with Bonferroni adjustment Multiple comparisons of symbolic capital received across the four visibility-based translator types

\begin{tabular}{|l|l|c|c|c|}
\hline Translator Type (I) & Translator Type (J) & Mean Rank Difference (I-J) & p-value & 0.0083 $^{*}$ \\
\hline Behind-the-scenes & Client-visible & -19.98 & 0.042 & No \\
\hline Behind-the-scenes & End-user-visible & -28.23 & 0.043 & No \\
\hline Behind-the-scenes & Visible & -26.61 & 0.014 & No \\
\hline Client-visible & End-user-visible & -8.25 & 0.638 & No \\
\hline Client-visible & Visible & -6.63 & 0.477 & No \\
\hline End-user-visible & Visible & 1.62 & 0.933 & No \\
\hline
\end{tabular}

* Due to the Bonferroni adjustment, the result can only be treated as significant if the p-value $<=0.05 / 6$, i.e., 0.0083 .

In order to further investigate any possible differences in the amount of symbolic capital received by the four types of translators, and to find out whether differences exist in any of the determinants (not normally distributed) of symbolic capital, we performed Kruskal-Wallis tests, crossing each of the determinants with the four visibility-based translator types. Table 10 indicates the existence of differences for one determinant (i.e., decision-making opportunities at work) for the four types of translators. However, the post-hoc tests, whose results are given in Table 11, only shows a statistically significant difference between the visible and the behind-thescenes translators $(\mathrm{p}=0.005)$. This means that visible translators statistically have greater opportunity to make decisions at work than behind-the-scenes translators.

Table 10 also indicates that, if we look at the highest mean rank, the end-uservisible translator has more opportunity to make decisions at work, feels better able to fulfill the expectations of clients and end-users, takes more pride in the profession, and receives more recognition for his/her role as a translator. However, it should be noted that these results are not statistically significant.

In this study, we expected the visible translator to receive the greatest amount of symbolic capital, but it is actually the end-user-visible translator who (by mean rank) enjoys more prestige and a higher status than other types of translators. We speculated that the cause of this difference is related to something in the nature of the end-user-visible translators (e.g., their job titles, the sector they are from, sex, age, regional location, work experience, level of education, major field of study, the time 
TABLE 10

Kruskal-Wallis test results for the eight determinants of symbolic capital received across the four visibility-based translator types

\begin{tabular}{|l|c|c|c|c|c|}
\hline & \multicolumn{3}{|c|}{ Mean Rank for symbolic capital } & \multirow{2}{*}{ p-value } \\
\cline { 2 - 6 } & Behind-the-scenes & Client-visible & End-user-visible & Visible & \\
\hline Work independently & 99.17 & 101.90 & 87.81 & 91.85 & 0.557 \\
\hline $\begin{array}{l}\text { Decision-making } \\
\text { opportunities at work }\end{array}$ & 85.35 & 91.08 & 117.09 & 111.43 & 0.013 \\
\hline $\begin{array}{l}\text { Fulfilling the expectation } \\
\text { of the client }\end{array}$ & 91.48 & 103.97 & 106.34 & 93.39 & 0.362 \\
\hline $\begin{array}{l}\text { Fulfilling the expectation } \\
\text { of the end-user }\end{array}$ & 87.51 & 96.16 & 115.28 & 103.91 & 0.127 \\
\hline Professional respect & 87.82 & 100.57 & 90.25 & 106.21 & 0.194 \\
\hline $\begin{array}{l}\text { The company's } \\
\text { reputation in the } \\
\text { industry }\end{array}$ & 85.84 & 99.49 & 99.16 & 107.12 & 0.145 \\
\hline $\begin{array}{l}\text { The pride of the } \\
\text { profession }\end{array}$ & 88.89 & 103.83 & 105.91 & 96.79 & 0.356 \\
\hline $\begin{array}{l}\text { The role of being a } \\
\text { translation professional }\end{array}$ & 90.42 & 100.10 & 111.38 & 97.33 & 0.432 \\
\hline
\end{tabular}

TABLE 11

Post-hoc tests for Kruskal-Wallis test - Mann-Whitney U tests with Bonferroni adjustment Multiple comparisons of the "decision-making opportunities at work" determinant across the four visibility-based translator types

\begin{tabular}{|l|l|c|c|c|}
\hline Translator Type (I) & Translator Type (J) & Mean Rank Difference (I-J) & p-value & $<\mathbf{0 . 0 0 8 3 \text { ? } ^ { * }}$ \\
\hline Behind-the-scenes & Client-visible & -5.71 & 0.586 & No \\
\hline Behind-the-scenes & End-user-visible & -31.74 & 0.021 & No \\
\hline Behind-the-scenes & Visible & -26.08 & 0.005 & Yes \\
\hline Client-visible & End-user-visible & -26.01 & 0.078 & No \\
\hline Client-visible & Visible & -20.35 & 0.045 & No \\
\hline End-user-visible & Visible & 5.66 & 0.765 & No \\
\hline
\end{tabular}

* Due to the Bonferroni adjustment, the result can only be treated as significant if the $\mathrm{p}$-value $<=0.05 / 6$, i.e., 0.0083 .

spent on translation-related assignments and whether or not their names appear on their translations). However, after completing the relevant tests, we find that these factors are not the causes. Thus, we cannot draw any conclusions based solely on the data we have gathered so far.

Overall, for symbolic capital, we can only confirm that the more visible senior experienced translators receive more symbolic capital, to a statistically significant extent, because they have more opportunity to make decisions at work, feel better able to fulfill the end-user's expectations, are more proud to be a part of their company, and have a better recognized role as a translator. On the other hand, the novice and experienced translators seem not to benefit from visibility in terms of the amount of symbolic capital received. The more visible novice translators may have less opportunity 
to work independently or to be recognized as translators, while the more visible experienced translators may have less opportunity to work independently or to fulfill client expectations, although it should be noted that the more visible the experienced translators, the more professional respect they obtain. Further, we found that the end-user-visible translator, who sometimes, often or very often communicates with the end-user but never or seldom communicates with the client, receives the greatest amount of symbolic capital by mean rank. This may be due to the fact that they feel they have more opportunity to make decisions at work, can better fulfill the expectations of clients and end-users, take more pride in their profession, and have a better recognized role as a translator.

\subsection{4. $H_{1 b}$ - The more visible the translators, the more economic capital they receive}

The results of the Spearman's rho correlation test, given in Table 12, show a weak correlation between the translator's visibility (not normally distributed) and the average amount of economic capital received (not normally distributed) (correlation coefficient $=0.167)$, with a high level of significance $(p=0.010)$. Table 12 also shows that the correlations between visibility and the economic capital received are moderate in the case of the novice translators (correlation coefficient $=0.217$ ) and the senior experienced translators (correlation coefficient $=0.227$ ), with high levels of significance ( $\mathrm{p}=0.035$ and 0.050 respectively). However, the correlation between visibility and the economic capital received is weak in the case of experienced translators (correlation coefficient $=0.078)$ and insignificant $(\mathrm{p}=0.262)$. As the results we obtained are not coherent, our second lower-level hypothesis, that the more visible translators receive more economic capital, can only be confirmed for the novice and senior experienced translators. In other words, the more visible novice and senior experienced translators may feel that they are earning more and have a more secure job.

TABLE 12

Spearman's rho correlation tests between the translator's visibility and the average amount of economic capital received

\begin{tabular}{|c|c|c|c|c|}
\hline & \multicolumn{4}{|c|}{ The translator's visibility } \\
\hline & All & Novice & Experienced & Senior Experienced \\
\hline Spearman's rho correlation & 0.167 & 0.217 & 0.078 & 0.227 \\
\hline p-value & 0.010 & 0.035 & 0.262 & 0.050 \\
\hline Mean economic capital ${ }^{\star}$ & 2.1062 & 1.9857 & 2.1667 & 2.1852 \\
\hline Mean visibility ${ }^{\star}$ & 0.3899 & 0.3679 & 0.3986 & 0.4074 \\
\hline
\end{tabular}

* For reference only (non-parametric tests do not rely on the distribution parameters, e.g., mean).

In this study, we expected the more visible translator to receive more economic capital. However, our statistical tests cannot confirm this once the work experience factor has been neutralized. In order to explain this phenomenon, we performed two Spearman's rho correlation tests (one-tailed) to look at which determinant gave the low scores.

Table 13 shows that, from a macro perspective, there are statistically significant relationships between the translator's visibility and the two determinants (salary and 
long-term job security) of the economic capital received (correlation coefficients = 0.129 and 0.153 , with $\mathrm{p}$-values $=0.037$ and 0.017 respectively). This suggests that the more visible the translators, the more money they earn and the more job security they have. However, when we look at the relationship between the three groups of translators (novice, experienced and senior experienced) and the two determinants of economic capital, the results of the Spearman's rho correlation tests, as shown in Table 13, reveal that only the more visible senior experienced translators are earning more money (correlation coefficient $=0.304$, with $\mathrm{p}=0.013$ ), while only the more visible novice translators feel that they have more job security (correlation coefficient $=0.253$, with $\mathrm{p}=0.017$ ).

TABLE 13

Spearman's rho correlation tests between the translator's visibility and the determinants of economic capital received

\begin{tabular}{|l|l|c|c|c|c|}
\hline & & All & Novice & Experienced & Senior Experienced \\
\hline \multirow{4}{*}{ Salary } & Mean & 2.0155 & 1.8857 & 2.0145 & 2.1852 \\
\cline { 2 - 6 } & $\begin{array}{l}\text { Correlation } \\
\text { coefficient }\end{array}$ & 0.129 & 0.111 & 0.013 & 0.304 \\
\cline { 2 - 6 } & p-value (1-tailed) & 0.037 & 0.180 & 0.457 & 0.013 \\
\hline \multirow{3}{*}{$\begin{array}{l}\text { Long-term job } \\
\text { security }\end{array}$} & Mean & 2.1969 & 2.0857 & 2.3188 & 2.1852 \\
\cline { 2 - 6 } & $\begin{array}{l}\text { Correlation } \\
\text { coefficient }\end{array}$ & 0.153 & 0.253 & 0.107 & 0.094 \\
\cline { 2 - 6 } & p-value (1-tailed) & 0.017 & 0.017 & 0.191 & 0.249 \\
\hline
\end{tabular}

* For reference only (non-parametric tests do not rely on the distribution parameters, e.g., mean).

When we study the differences in the amount of economic capital (not normally distributed) received by the four visibility-based translator types - behind-the-scenes, client-visible, end-user-visible and visible translators - the result of the KruskalWallis test indicates statistically significant differences $(p=0.044)$. The descriptive statistics, given in Table 14, show that, by mean rank, the end-user-visible translator is ranked highest, followed by the visible translator, the client-visible translator, and finally the behind-the-scenes translator.

However, the post-hoc tests, whose results are given in Table 15, show no statistically significant difference between the four types of translators in terms of the economic capital received.

TABLE 14

Descriptive statistics - the average amount of economic capital received across the four visibility-based translator types

\begin{tabular}{|l|c|c|c|c|}
\hline & $\mathbf{N}$ & $\begin{array}{c}\text { Mean economic } \\
\text { capital received }^{\star}\end{array}$ & $\begin{array}{c}\text { Median economic } \\
\text { capital received }\end{array}$ & $\begin{array}{c}\text { Mean rank for economic } \\
\text { capital received }\end{array}$ \\
\hline Behind-the-scenes & 65 & 1.8769 & 2.0000 & 81.57 \\
\hline Client-visible & 58 & 2.1724 & 2.0000 & 102.13 \\
\hline End-user-visible & 16 & 2.3125 & 2.2500 & 111.25 \\
\hline Visible & 54 & 2.2500 & 2.5000 & 105.84 \\
\hline Total & $\mathbf{1 9 3}$ & $\mathbf{2 . 1 0 6 2}$ & $\mathbf{2 . 0 0 0 0}$ & - \\
\hline
\end{tabular}


TABLE 15

Post-hoc tests for Kruskal-Wallis test - Mann-Whitney U tests with Bonferroni adjustment Multiple comparisons of the economic capital received across the four visibility-based translator types

\begin{tabular}{|l|l|c|c|c|}
\hline Translator Type (I) & Translator Type (J) & Mean Rank Difference (I-J) & p-value & ${\text { 0.0083 }{ }^{*}}^{*}$ \\
\hline Behind-the-scenes & Client-visible & -20.56 & 0.043 & No \\
\hline Behind-the-scenes & End-user-visible & -29.68 & 0.042 & No \\
\hline Behind-the-scenes & Visible & -24.27 & 0.016 & No \\
\hline Client-visible & End-user-visible & -9.12 & 0.602 & No \\
\hline Client-visible & Visible & -3.71 & 0.740 & No \\
\hline End-user-visible & Visible & 5.41 & 0.770 & No \\
\hline
\end{tabular}

* Due to the Bonferroni adjustment, the result can only be treated as significant if the p-value $<=0.05 / 6$, i.e., 0.0083 .

In order to further investigate any possible differences in the amount of economic capital received by the four types of translators, and to find out whether differences exist in any of the determinants (not normally distributed) of economic capital, we performed Kruskal-Wallis tests, crossing each of the determinants with the four visibility-based translator types. The results, given in Table 16, show no significant difference $(p>0.05)$ between the economic capital received by the four types of translators.

TABLE 16

Kruskal-Wallis test results for the two determinants of economic capital received across the four visibility-based translator types

\begin{tabular}{|l|c|c|c|c|c|}
\hline & \multicolumn{3}{|c|}{ Mean rank for economic capital } & \multirow{2}{*}{ p-value } \\
\cline { 2 - 5 } & Behind-the-scenes & Client-visible & End-user-visible & Visible & \\
\hline Salary & 84.25 & 103.23 & 108.13 & 102.35 & 0.125 \\
\hline Long-term job security & 84.51 & 98.48 & 109.66 & 106.69 & 0.095 \\
\hline
\end{tabular}

How can we explain these results? We have logically speculated that the cause of the difference is related to something in the nature of the end-user-visible translators (e.g., their job titles, the sector they are from, sex, age, regional location, work experience, level of education, major field of study, the time spent on translationrelated assignment and whether or not their names appear on their translations). However, after completing the relevant tests, we find that once again, these factors are not the causes. Therefore, we still cannot draw any conclusions based solely on the data we have gathered so far.

Overall, for economic capital, we can only confirm that the more visible novice translators and the more visible senior experienced translators receive more economic capital, to a statistically significant extent, because the novice translator has more job security, while the senior experienced translator earns more money. Further, we observe that, by mean rank, the end-user-visible translator receives the greatest amount of economic capital, followed by the visible translator, the client-visible translator, and finally the behind-the-scenes translator. Although the differences are not statistically significant, and we cannot explain the results based on the data we have collected, this relationship is worth noting because we expected the visible translator to receive the greatest amount of economic capital, whereas it is the 
end-user-visible translator who actually earns more money and has greater job security than the other types of translators.

\subsection{5. $H_{1 c}$ - The more visible the translators, the more social capital they receive}

Table 17 shows that, for hypothesis $\mathrm{H}_{1 \mathrm{c}}$, all the correlations are positive and strong, with high levels of significance. The correlation coefficients between the translator's visibility (not normally distributed) and the social capital received (not normally distributed) are 0.299 (novice translator), 0.363 (experienced translator) and 0.315 (senior experienced translator), with $\mathrm{p}=0.006,0.001$ and 0.010 respectively. In addition, the overall correlation between the two dependent variables is strong (correlation coefficient $=0.323)$ with an extremely high level of significance $(\mathrm{p}<0.001)$. Therefore we can conclude that, in our sample, the third lower-level hypothesis - that the more visible translators receive more social capital - has been statistically confirmed. This means that the more visible translators feel that they know more people.

TABLE 17

Spearman's rho correlation tests between the translator's visibility and the average amount of social capital received

\begin{tabular}{|l|c|c|c|c|}
\hline \multirow{2}{*}{} & \multicolumn{4}{|c|}{ The translator's visibility } \\
\cline { 2 - 5 } & All & Novice & Experienced & Senior Experienced \\
\hline Spearman's rho correlation & 0.323 & 0.299 & 0.363 & 0.315 \\
\hline p-value & $<0.001$ & 0.006 & 0.001 & 0.010 \\
\hline Mean social capital & 2.3886 & 2.3048 & 2.4034 & 2.4784 \\
\hline Mean visibility $^{*}$ & 0.3899 & 0.3679 & 0.3986 & 0.4074 \\
\hline
\end{tabular}

* For reference only (non-parametric tests do not rely on the distribution parameters, e.g., mean).

To explain why the more visible translators receive more social capital, we performed 24 Spearman's rho correlation tests (one-tailed). According to Table 18, the more visible translators can make more valuable personal contacts $(p=0.001)$, have more opportunity to move between roles $(\mathrm{p}=0.008)$, have a greater chance to work with people both in the same profession $(\mathrm{p}=0.043)$ and in different professions $(\mathrm{p}<0.001)$, and have more opportunity to receive recognition from clients $(\mathrm{p}=0.002)$ and end-users $(p<0.001)$ when they have done a good job. Then, we examine whether the results are coherent for the three experience groups.

As Table 18 shows, the novice translator, whose translation experience does not exceed three years, seems to benefit greatly from visibility, because the more visible the novice translators, the more opportunity they have to work with people, no matter whether the people are from the same profession $(\mathrm{p}=0.033)$ or different professions $(\mathrm{p}=0.021)$. The more visible the novice translators, the more opportunity to receive recognition from clients $(p=0.016)$ and end-users $(p=0.036)$ they have. Meanwhile, the more visible experienced translators, whose translation experience is between three and seven years, can make more valuable personal contacts ( $\mathrm{p}=0.001)$, have more opportunity to move between roles $(\mathrm{p}=0.005)$ and have a greater chance to work with people from different professions $(\mathrm{p}<0.001)$. Finally, the more visible senior experienced translators, whose translation experience exceeds seven years, have more opportunity to receive recognition from clients $(\mathrm{p}=0.012)$ and end-users $(\mathrm{p}=<0.001)$ when they have done a good job. 
TABLE 18

Spearman's rho correlation tests between translator visibility and determinants of social capital received

\begin{tabular}{|c|c|c|c|c|c|}
\hline & & All & Novice & Experienced & $\begin{array}{c}\text { Senior } \\
\text { Experienced }\end{array}$ \\
\hline \multirow{3}{*}{$\begin{array}{l}\text { A working environment } \\
\text { that allows the person to } \\
\text { strengthen the personal } \\
\text { network }\end{array}$} & Mean $^{\star}$ & 2.3523 & 2.3286 & 2.3478 & 2.3889 \\
\hline & Correlation coefficient & 0.235 & 0.171 & 0.363 & 0.196 \\
\hline & p-value (1-tailed) & 0.001 & 0.078 & 0.001 & 0.078 \\
\hline \multirow{3}{*}{$\begin{array}{l}\text { Moving between roles so } \\
\text { that the person is not } \\
\text { limited to doing } \\
\text { translation only }\end{array}$} & Mean $^{*}$ & 2.6321 & 2.6857 & 2.5797 & 2.6296 \\
\hline & Correlation coefficient & 0.173 & 0.083 & 0.306 & 0.117 \\
\hline & p-value (1-tailed) & 0.008 & 0.247 & 0.005 & 0.200 \\
\hline \multirow{3}{*}{$\begin{array}{l}\text { Opportunity to work with } \\
\text { people of the translation } \\
\text { profession }\end{array}$} & Mean $^{*}$ & 2.0052 & 1.8429 & 2.0435 & 2.1667 \\
\hline & Correlation coefficient & 0.124 & 0.221 & 0.091 & 0.014 \\
\hline & p-value (1-tailed) & 0.043 & 0.033 & 0.228 & 0.459 \\
\hline \multirow{3}{*}{$\begin{array}{l}\text { Opportunity to work with } \\
\text { people from different } \\
\text { professions }\end{array}$} & Mean $^{\star}$ & 2.1813 & 2.1714 & 2.1884 & 2.1852 \\
\hline & Correlation coefficient & 0.254 & 0.244 & 0.389 & 0.145 \\
\hline & p-value (1-tailed) & $<0.001$ & 0.021 & $<0.001$ & 0.148 \\
\hline \multirow{3}{*}{$\begin{array}{l}\text { The client's appreciation of } \\
\text { the person's translation } \\
\text { work }\end{array}$} & Mean $^{\star}$ & 2.7720 & 2.5714 & 2.8406 & 2.9444 \\
\hline & Correlation coefficient & 0.211 & 0.257 & 0.086 & 0.307 \\
\hline & p-value (1-tailed) & 0.002 & 0.016 & 0.242 & 0.012 \\
\hline \multirow{3}{*}{$\begin{array}{l}\text { The end-user's } \\
\text { appreciation of the } \\
\text { person's translation work }\end{array}$} & Mean $^{*}$ & 2.3886 & 2.2286 & 2.4203 & 2.5556 \\
\hline & Correlation coefficient & 0.257 & 0.217 & 0.147 & 0.436 \\
\hline & p-value (1-tailed) & $<0.001$ & 0.036 & 0.114 & $<0.001$ \\
\hline
\end{tabular}

* For reference only (non-parametric tests do not rely on the distribution parameters, e.g., mean).

When we investigated the differences in the amount of social capital received by the four visibility-based translator types, the Kruskal-Wallis test indicates a statistically significant result $(\mathrm{p}<0.001)$. The descriptive statistics are given in Table 19.

TABLE 19

Descriptive statistics - the average amount of social capital received across the four visibility-based translator types

\begin{tabular}{|l|c|c|c|c|}
\hline & N & $\begin{array}{c}\text { Mean social capital } \\
\text { received }^{*}\end{array}$ & $\begin{array}{c}\text { Median social capital } \\
\text { received }\end{array}$ & $\begin{array}{c}\text { Mean rank for social } \\
\text { capital received }\end{array}$ \\
\hline Behind-the-scenes & 65 & 2.2308 & 2.1667 & 82.18 \\
\hline Client-visible & 58 & 2.2241 & 2.1667 & 81.90 \\
\hline End-user-visible & 16 & 2.4792 & 2.5833 & 102.28 \\
\hline Visible & 54 & 2.7284 & 2.8333 & 129.50 \\
\hline Total & 193 & 2.3886 & 2.5000 & - \\
\hline
\end{tabular}

* For reference only (non-parametric tests do not rely on the distribution parameters, e.g., mean).

Table 19 shows that, by mean rank, the visible translator receives the greatest amount of social capital, followed by the end-user-visible translator, the behind-thescenes translator, and finally the client-visible translator. The post-hoc tests, whose results are given in Table 20, indicate that the difference between behind-the-scenes and visible translators is significant $(\mathrm{p}<0.001)$, as is the difference between client- 
visible and visible translators $(\mathrm{p}<0.001)$. These results mean that, to a statistically significant extent, the visible translator knows more people than the client-visible and behind-the-scenes translators. As the difference between the visible translator and the end-user-visible translator is not statistically significant, we can only say that, by mean rank, the visible translator knows more people than the end-user-visible translator.

TABLE 20

Post-hoc tests for Kruskal-Wallis test - Mann-Whitney U tests with Bonferroni adjustment Multiple comparisons of the social capital received across the four visibility-based translator types

\begin{tabular}{|l|l|c|c|c|}
\hline Translator Type (I) & Translator Type (J) & Mean Rank Difference (I-J) & p-value & $<\mathbf{0 . 0 0 8 3 ? ^ { * }}$ \\
\hline Behind-the-scenes & Client-visible & 0.28 & 0.947 & No \\
\hline Behind-the-scenes & End-user-visible & -20.10 & 0.118 & No \\
\hline Behind-the-scenes & Visible & -47.32 & $<0.001$ & Yes \\
\hline Client-visible & End-user-visible & -20.38 & 0.137 & No \\
\hline Client-visible & Visible & -47.60 & $<0.001$ & Yes \\
\hline End-user-visible & Visible & -27.22 & 0.025 & No \\
\hline
\end{tabular}

* Due to the Bonferroni adjustment, the result can only be treated as significant if the $\mathrm{p}$-value $<=0.05 / 6$, i.e., 0.0083 .

In order to further investigate whether differences exist in any of the determinants (not normally distributed) of social capital received by the four types of translators, we performed Kruskal-Wallis tests, crossing each of the determinants with the four visibility-based translator types. Table 21 indicates significant differences for four determinants, including (1) a working environment that allows the subjects to strengthen their personal networks; (2) moving between roles; (3) the opportunity to work with people from different professions; and (4) the opportunity to receive the appreciation of end-users for the subjects' translations. The post-hoc tests, whose results are given in Table 22, show that the visible translators can better strengthen their personal networks in their workplaces, have more opportunity to move between roles, have a greater chance to work with people from different professions, and have more opportunity to receive the end-user's recognition than do the client-visible and the behind-the-scenes translators. Meanwhile, the end-user-visible translators have more opportunity to move between roles than do the behind-the-scenes and the client-visible translators. Also, the end-user-visible translators have a greater chance to receive recognition from their end-users than the client-visible translators.

Overall, for social capital, we can confirm in a statistically significant way that the more visible translators receive more social capital. In addition, we have found, to a statistically significant extent, that the visible translator knows more people than the client-visible and behind-the-scenes translators. The visible translator also knows more people than the end-user-visible translator by mean rank, although the difference is not statistically significant. 
TABLE 21

Kruskal-Wallis test results for the six determinants of social capital received across the four visibility-based translator types

\begin{tabular}{|l|c|c|c|c|c|}
\hline & \multicolumn{3}{|c|}{ Mean Rank for social capital } & \multirow{2}{*}{ p-value } \\
\cline { 2 - 6 } & Behind-the-scenes & Client-visible & End-user-visible & Visible & \\
\hline $\begin{array}{l}\text { A working environment that } \\
\text { allows the person to strengthen } \\
\text { the personal network }\end{array}$ & 86.22 & 85.16 & 109.06 & 119.11 & 0.001 \\
\hline $\begin{array}{l}\text { Moving between roles so that } \\
\text { the person is not limited to } \\
\text { doing translation only }\end{array}$ & 87.12 & 82.97 & 126.28 & 115.29 & $<0.001$ \\
\hline $\begin{array}{l}\text { Opportunity to work with } \\
\text { people of the translation } \\
\text { profession }\end{array}$ & 91.12 & 98.56 & 78.31 & 107.94 & 0.166 \\
\hline $\begin{array}{l}\text { Opportunity to work with } \\
\text { people from different } \\
\text { professions }\end{array}$ & 84.65 & 85.53 & 98.94 & 123.62 & $<0.001$ \\
\hline $\begin{array}{l}\text { The client's appreciation of the } \\
\text { person's translation work }\end{array}$ & 89.52 & 98.69 & 77.88 & 109.86 & 0.053 \\
\hline $\begin{array}{l}\text { The end-user's appreciation of } \\
\text { the person's translation work }\end{array}$ & 89.22 & 77.06 & 113.66 & 122.85 & $<0.001$ \\
\hline
\end{tabular}

TABLE 22

Post-hoc tests for Kruskal-Wallis tests - Mann-Whitney U tests with Bonferroni adjustment Multiple comparisons of the four determinants of social capital received across the four visibility-based translator types

\begin{tabular}{|c|c|c|c|c|c|}
\hline & Translator Type (I) & Translator Type (J) & $\begin{array}{c}\text { Mean Rank } \\
\text { Difference (I-J) }\end{array}$ & p-value & $<0.0083$ ? \\
\hline \multirow{6}{*}{$\begin{array}{l}\text { A working } \\
\text { environment that } \\
\text { allows the person to } \\
\text { strengthen the } \\
\text { personal network }\end{array}$} & Behind-the-scenes & Client-visible & 1.06 & 0.848 & No \\
\hline & \begin{tabular}{|l|} 
Behind-the-scenes \\
\end{tabular} & End-user-visible & -22.84 & 0.090 & No \\
\hline & Behind-the-scenes & Visible & -32.89 & 0.001 & Yes \\
\hline & Client-visible & End-user-visible & -23.90 & 0.098 & No \\
\hline & Client-visible & \begin{tabular}{|l|} 
Visible \\
\end{tabular} & -33.95 & 0.001 & Yes \\
\hline & End-user-visible & Visible & -10.05 & 0.364 & No \\
\hline \multirow{6}{*}{$\begin{array}{l}\text { Moving between roles } \\
\text { so that the person is } \\
\text { not limited to doing } \\
\text { translation only }\end{array}$} & Behind-the-scenes & Client-visible & 4.16 & 0.632 & No \\
\hline & Behind-the-scenes & End-user-visible & -39.16 & 0.005 & Yes \\
\hline & Behind-the-scenes & Visible & -28.16 & 0.003 & Yes \\
\hline & Client-visible & End-user-visible & -43.32 & 0.003 & Yes \\
\hline & Client-visible & Visible & -32.32 & 0.001 & Yes \\
\hline & End-user-visible & Visible & 10.99 & 0.531 & No \\
\hline \multirow{6}{*}{$\begin{array}{l}\text { Opportunity to work } \\
\text { with people from } \\
\text { different professions }\end{array}$} & Behind-the-scenes & Client-visible & -0.88 & 0.971 & No \\
\hline & Behind-the-scenes & End-user-visible & -14.29 & 0.256 & No \\
\hline & \begin{tabular}{|l|} 
Behind-the-scenes \\
\end{tabular} & Visible & -38.97 & $<0.001$ & Yes \\
\hline & Client-visible & End-user-visible & -13.41 & 0.297 & No \\
\hline & Client-visible & Visible & -38.09 & $<0.001$ & Yes \\
\hline & End-user-visible & Visible & -24.68 & 0.038 & No \\
\hline \multirow{6}{*}{$\begin{array}{l}\text { The end-user's } \\
\text { appreciation of the } \\
\text { person's translation } \\
\text { work }\end{array}$} & Behind-the-scenes & Client-visible & 12.16 & 0.278 & No \\
\hline & Behind-the-scenes & End-user-visible & -24.44 & 0.110 & No \\
\hline & \begin{tabular}{|l|} 
Behind-the-scenes \\
\end{tabular} & Visible & -33.64 & 0.001 & Yes \\
\hline & Client-visible & End-user-visible & -36.60 & 0.007 & Yes \\
\hline & \begin{tabular}{|l} 
Client-visible \\
\end{tabular} & \begin{tabular}{|l|} 
Visible \\
\end{tabular} & -45.79 & $<0.001$ & Yes \\
\hline & End-user-visible & Visible & -9.20 & 0.478 & No \\
\hline
\end{tabular}

* Due to the Bonferroni adjustment, the result can only be treated as significant if the p-value $<=0.05 / 6$, i.e., 0.0083 . 


\subsection{6. $H_{1 d}$ - The more visible the translators, the more cultural capital they receive}

Table 23 shows that all the Spearman's rho correlations between visibility (not normally distributed) and the cultural capital received (normally distributed) are positive and at least moderate, with high levels of significance. The correlation coefficients between the translator's visibility and the cultural capital that the novice, experienced and senior experienced translators say they receive are 0.336 (strong), 0.238 (moderate) and 0.422 (strong), with $\mathrm{p}=0.002,0.024,0.001$ respectively. Further, the overall correlation between the translator's visibility and the average amount of cultural capital received is strong (correlation coefficient $=0.321$ ), with an extremely high level of significance $(\mathrm{p}<0.001)$. Thus we can conclude that, in our sample, the fourth lower-level hypothesis - that the more visible the translators the more cultural capital they receive - has been confirmed in a statistically significant way. This means that the more visible translators feel they are learning more.

TABLE 23

Spearman's rho correlation tests between the translator's visibility and the average amount of cultural capital received

\begin{tabular}{|l|c|c|c|c|}
\hline \multirow{2}{*}{} & \multicolumn{4}{|c|}{ The translator's visibility } \\
\cline { 2 - 5 } & All & Novice & Experienced & Senior Experienced \\
\hline Spearman's rho correlation & 0.321 & 0.336 & 0.238 & 0.422 \\
\hline p-value & $<0.001$ & 0.002 & 0.024 & 0.001 \\
\hline Mean cultural capital $^{\star}$ & 2.6416 & 2.5881 & 2.6377 & 2.7160 \\
\hline Mean visibility $^{*}$ & 0.3899 & 0.3679 & 0.3986 & 0.4074 \\
\hline
\end{tabular}

* For reference only (non-parametric tests do not rely on the distribution parameters, e.g., mean).

To explain why the more visible translators learn more, we performed 24 Spearman's rho correlation tests (one-tailed) to look at the correlations between actual determinants (not normally distributed) and visibility (not normally distributed). Table 24 shows that the more visible translators, no matter what their level of experience, receive more feedback from clients and end-users, since the results are significant $(\mathrm{p}<0.05)$ for all the three "experience" groups of translators. Further, the more visible novice translators, whose translation experience does not exceed three years, have more opportunity to boost their professional qualifications $(p=0.018)$, while the more visible senior experienced translators, who have more than seven years' translation experience, have a greater chance to use their skills and expertise $(\mathrm{p}=0.036)$. 
TABLE 24

Spearman's rho correlation tests between the translator's visibility and the determinants of cultural capital received

\begin{tabular}{|c|c|c|c|c|c|}
\hline & & All & Novice & Experienced & $\begin{array}{c}\text { Senior } \\
\text { Experienced }\end{array}$ \\
\hline \multirow{3}{*}{$\begin{array}{l}\text { Opportunity to learn } \\
\text { new knowledge }\end{array}$} & Mean $^{*}$ & 3.1969 & 3.2143 & 3.1739 & 3.2037 \\
\hline & Correlation coefficient & 0.093 & 0.015 & 0.097 & 0.196 \\
\hline & p-value (1-tailed) & 0.099 & 0.452 & 0.213 & 0.078 \\
\hline \multirow{3}{*}{$\begin{array}{l}\text { Opportunity to } \\
\text { improve translation } \\
\text { skills }\end{array}$} & Mean* & 3.2228 & 3.2143 & 3.1884 & 3.2778 \\
\hline & Correlation coefficient & 0.027 & -0.083 & 0.030 & 0.204 \\
\hline & p-value (1-tailed) & 0.356 & 0.248 & 0.403 & 0.070 \\
\hline \multirow{3}{*}{$\begin{array}{l}\text { Opportunity to boost } \\
\text { professional } \\
\text { qualification }\end{array}$} & Mean* $^{*}$ & 2.8549 & 2.7857 & 2.8116 & 3.0000 \\
\hline & Correlation coefficient & 0.197 & 0.250 & 0.188 & 0.176 \\
\hline & p-value (1-tailed) & 0.003 & 0.018 & 0.061 & 0.102 \\
\hline \multirow{3}{*}{$\begin{array}{l}\text { Opportunity to use the } \\
\text { person's skills and } \\
\text { expertise at work }\end{array}$} & Mean $^{*}$ & 2.8342 & 2.7571 & 2.7971 & 2.9815 \\
\hline & Correlation coefficient & 0.127 & 0.134 & 0.067 & 0.247 \\
\hline & p-value (1-tailed) & 0.039 & 0.135 & 0.293 & 0.036 \\
\hline \multirow{3}{*}{$\begin{array}{l}\text { Feedback on the } \\
\text { person's translated } \\
\text { work from the client }\end{array}$} & Mean $^{*}$ & 2.0777 & 1.8857 & 2.1739 & 2.2037 \\
\hline & Correlation coefficient & 0.303 & 0.389 & 0.260 & 0.227 \\
\hline & p-value (1-tailed) & $<0.001$ & $<0.001$ & 0.015 & 0.049 \\
\hline \multirow{3}{*}{$\begin{array}{l}\text { Feedback on the } \\
\text { person's translated } \\
\text { work from the end-user }\end{array}$} & Mean $^{\star}$ & 1.6632 & 1.6714 & 1.6812 & 1.6296 \\
\hline & Correlation coefficient & 0.340 & 0.336 & 0.293 & 0.436 \\
\hline & p-value (1-tailed) & $<0.001$ & 0.002 & 0.007 & $<0.001$ \\
\hline
\end{tabular}

* For reference only (non-parametric tests do not rely on the distribution parameters, e.g., mean).

An important observation from Table 24 is the negative relationship between the visibility of the novice translators and their opportunity to improve their translation skills (correlation coefficient $=-0.083$ ), although it should be noted that the result is not significant $(\mathrm{p}=0.248)$. This suggests that the more visible novice translators may have less opportunity to improve their translation skills, although we have already found that these same visible translators have a greater chance to boost their professional qualifications. While we cannot explain this difference based solely on the data we have collected, we suspect that the "professional qualifications" may not always be related to translation. For example, some visible novice translators are public relations executives; their visibility may boost their professional qualifications in communication or public relations, but not in translation. This may be an area for future research.

When we examined the differences in the amount of cultural capital (normally distributed) received by the four visibility-based translator types, the result of the ANOVA test indicates statistically significant differences between the average scores for the four types of translators $(\mathrm{p}<0.001)$. The means are given in Table 25 . 
TABLE 25

Descriptive statistics - the average amount of cultural capital received across the four visibility-based translator types

\begin{tabular}{|l|c|c|c|c|c|}
\hline & $\mathbf{N}$ & $\begin{array}{c}\text { Mean Cultural } \\
\text { Capital Received }\end{array}$ & $\begin{array}{c}\text { Median Cultural } \\
\text { Capital Received }\end{array}$ & $\begin{array}{c}\text { Minimum } \\
\text { Cultural Capital } \\
\text { Received }\end{array}$ & $\begin{array}{c}\text { Maximum } \\
\text { Cultural Capital } \\
\text { Received }\end{array}$ \\
\hline Behind-the-scenes & 65 & 2.4333 & 2.5000 & 1.1667 & 3.5000 \\
\hline Client-visible & 58 & 2.6149 & 2.6667 & 0.3333 & 3.6667 \\
\hline End-user-visible & 16 & 2.8125 & 2.7500 & 2.3333 & 3.6667 \\
\hline Visible & 54 & 2.8704 & 2.8333 & 1.5000 & 4.0000 \\
\hline Total & 193 & 2.6416 & 2.6667 & 0.3333 & 4.0000 \\
\hline
\end{tabular}

Table 25 indicates that the visible translator receives the greatest amount of cultural capital, followed by the end-user-visible translator, the client-visible translator, and the behind-the-scenes translator. However, the Scheffe post-hoc tests, whose results are given in Table 26, only allow us to statistically confirm that the visible translator receives more cultural capital than does the behind-the-scenes translator $(\mathrm{p}<0.001)$.

\section{TABLE 26}

Scheffe post-hoc tests for ANOVA - Multiple comparisons of the cultural capital received across the four visibility-based translator types

\begin{tabular}{|l|l|c|c|c|}
\hline Translator Type (I) & Translator Type (J) & Mean Difference (I-J) & p-value & $<\mathbf{0 . 0 5} ?$ \\
\hline Behind-the-scenes & Client-visible & -0.1816 & 0.293 & No \\
\hline Behind-the-scenes & End-user-visible & -0.3792 & 0.080 & No \\
\hline Behind-the-scenes & Visible & -0.4370 & $<0.001$ & Yes \\
\hline Client-visible & End-user-visible & -0.1976 & 0.612 & No \\
\hline Client-visible & Visible & -0.2554 & 0.083 & No \\
\hline End-user-visible & Visible & -0.0579 & 0.985 & No \\
\hline
\end{tabular}

In order to further investigate whether differences exist in any of the determinants (not normally distributed) of cultural capital received by the four types of translators, we performed Kruskal-Wallis tests, crossing each of the determinants with the four visibility-based translator types. The results, given in Table 27, show significant differences for only two determinants: the feedback that the subjects receive from clients $(\mathrm{p}<0.001)$ and from end-users $(\mathrm{p}<0.001)$. The post-hoc tests (Table 28) indicate that the visible translator receives more feedback from the client than does the behind-the-scenes translator. Further, visible and end-user-visible translators receive more feedback from the end-user than do behind-the-scenes and client-visible translators. 
TABLE 27

Kruskal-Wallis test results for the six determinants of cultural capital received across the four visibility-based translator types

\begin{tabular}{|c|c|c|c|c|c|}
\hline & \multicolumn{4}{|c|}{ Mean Rank for cultural capital } & \multirow[b]{2}{*}{ p-value } \\
\hline & $\begin{array}{l}\text { Behind-the- } \\
\text { scenes }\end{array}$ & $\begin{array}{l}\text { Client- } \\
\text { visible }\end{array}$ & $\begin{array}{l}\text { End-user- } \\
\text { visible }\end{array}$ & Visible & \\
\hline $\begin{array}{l}\text { Opportunity to learn new } \\
\text { knowledge }\end{array}$ & 89.35 & 106.28 & 91.78 & 97.79 & 0.252 \\
\hline $\begin{array}{l}\text { Opportunity to improve } \\
\text { translation skills }\end{array}$ & 94.77 & 102.74 & 92.38 & 94.89 & 0.742 \\
\hline $\begin{array}{l}\text { Opportunity to boost professional } \\
\text { qualification }\end{array}$ & 86.64 & 99.68 & 99.75 & 105.78 & 0.214 \\
\hline $\begin{array}{l}\text { Opportunity to use the person's } \\
\text { skills and expertise at work }\end{array}$ & 87.05 & 96.72 & 102.16 & 107.76 & 0.134 \\
\hline $\begin{array}{l}\text { Feedback on the person's } \\
\text { translated work from the client }\end{array}$ & 75.38 & 100.52 & 101.06 & 118.05 & $<0.001$ \\
\hline $\begin{array}{l}\text { Feedback on the person's } \\
\text { translated work from the end-user }\end{array}$ & 76.89 & 80.17 & 134.84 & 128.06 & $<0.001$ \\
\hline
\end{tabular}

TABLE 28

Post hoc tests for Kruskal-Wallis tests - Mann-Whitney U tests with Bonferroni adjustment - Multiple comparisons of the two determinants of cultural capital received across the four visibility-based translator types

\begin{tabular}{|c|c|c|c|c|c|}
\hline & Translator Type (I) & Translator Type (J) & $\begin{array}{c}\text { Mean Rank } \\
\text { Difference (I-J) }\end{array}$ & p-value & $<0.0083$ ? $^{*}$ \\
\hline \multirow{6}{*}{$\begin{array}{l}\text { Feedback on the } \\
\text { person's } \\
\text { translated work } \\
\text { from the client }\end{array}$} & Behind-the-scenes & Client-visible & -25.14 & 0.012 & No \\
\hline & Behind-the-scenes & End-user-visible & -25.69 & 0.071 & No \\
\hline & Behind-the-scenes & Visible & -42.67 & $<0.001$ & Yes \\
\hline & Client-visible & End-user-visible & -0.55 & 0.967 & No \\
\hline & \begin{tabular}{|l|} 
Client-visible \\
\end{tabular} & \begin{tabular}{|l|} 
Visible \\
\end{tabular} & -17.53 & 0.103 & No \\
\hline & End-user-visible & Visible & -16.98 & 0.234 & No \\
\hline \multirow{6}{*}{$\begin{array}{l}\text { Feedback on the } \\
\text { person's } \\
\text { translated work } \\
\text { from the end-user }\end{array}$} & Behind-the-scenes & Client-visible & -3.28 & 0.732 & No \\
\hline & Behind-the-scenes & End-user-visible & -57.95 & $<0.001$ & Yes \\
\hline & Behind-the-scenes & Visible & -51.17 & $<0.001$ & Yes \\
\hline & Client-visible & End-user-visible & -54.67 & $<0.001$ & Yes \\
\hline & Client-visible & Visible & -47.89 & $<0.001$ & Yes \\
\hline & End-user-visible & Visible & 6.78 & 0.603 & No \\
\hline
\end{tabular}

* Due to the Bonferroni adjustment, the result can only be treated as significant if the p-value $<=0.05 / 6$, i.e., 0.0083 .

Overall, for cultural capital, we have confirmed, to a statistically significant extent, the hypothesis that the more visible translators receive more cultural capital, because the more visible translators, no matter their level of experience, receive more feedback from clients and end-users. The more visible novice translators have more opportunity to boost their professional qualifications, while the visible senior experienced translators have a greater chance to use their skills and expertise. Finally, we have found that the visible translator receives more feedback from the client than the behind-the-scenes translator, while the visible and the end-user-visible translators receive more feedback from the end-user than do the behind-the-scenes and the client-visible translators. 
After testing the above hypotheses, we now summarize what we have found. It is worth recalling that our focus is on the visibility-capital relationship and thus we have tried to avoid the influence of the work experience factor when testing the hypotheses. In our study, we have statistically shown that, for this sample, the more visible the translator, the more capital they receive. Among the four kinds of capital, the correlations between the translator's visibility and the symbolic as well as the economic capital that the translators say they receive are weak and insignificant. Therefore, the two lower-level hypotheses - the more visible the translators, the more symbolic and economic capital they receive - are not statistically confirmed. However, the correlations between the translator's visibility and the social as well as the cultural capital that the translators say they receive are strong and significant. Thus, the two lower-level hypotheses, that the more visible the translators the more social and cultural capital they receive, are confirmed in a statistically significant way. These test results suggest that people may not receive more money or enjoy higher prestige/status when they are visible to their clients and end-users. However, when they are visible, they do have a stronger social network, and they feel that they are learning more.

\subsection{Further analysis}

In the first part of our questionnaire, we collected data on the background information of the subjects. Questions including sex (nominal), age (ordinal), regional location (nominal), level of education (ordinal), major field of study (the highest level) (nominal), time spent working on translation assignments (continuous, but not normally distributed, $\mathrm{p}=0.001$, given by the Kolmogorov-Smirnov test), and whether or not the translator's name appeared on the translations were asked (continuous, but not normally distributed, $\mathrm{p}<0.001$, given by the Kolmogorov-Smirnov test). In this part, we analyze the relationship between the two dependent variables visibility and capital and the seven background variables sex, age, regional location, level of education, major field of study, time spent working on translation assignments and whether the translator's name appeared on the translations.

\subsubsection{Sex}

The relationship between sex and the translator's visibility was investigated using an independent sample Mann-Whitney U test (two-tailed). The mean ranks of visibility are 97.16 for women and 96.79 for men. The test comparing the translator's visibility across sexes finds no significant difference $(\mathrm{p}=0.963)$. The result suggests that sex is not related to the level of the translator's visibility.

An independent sample t-test (two-tailed) was performed to analyze the relationship between sex and the capital that the respondents said they received. The means of the capital received are 2.5325 for women and 2.6234 for men. An independent sample t-test comparing the amount of capital that the respondents said they receive across sexes finds no significant difference $(\mathrm{p}=0.132)$. This result also suggests that sex is not related to the amount of capital that the translators say they receive. 


\subsubsection{Age}

The relationship between age and the translator's visibility was calculated using a Spearman's rho correlation (two-tailed). No correlation is found (correlation coefficient $=0.025, \mathrm{p}=0.731$ ) between the two variables. We also used the Spearman's rho correlation (two-tailed) to examine the relationship between age and the amount of capital received. An insignificant weak positive correlation is found (correlation coefficient $=0.133, \mathrm{p}=0.065$ ) between the two variables. This result suggests that the older the translator, the more capital they may receive.

\subsubsection{Regional location}

A Kruskal-Wallis test was used to analyze the differences in terms of the translator's visibility between the regions that the subjects live. The result shows that no significant difference $(\mathrm{p}=0.082)$.

ANOVA was used to compare the differences in terms of the capital received between the regions that the subjects lived in. Again, no significant difference ( $\mathrm{p}=$ 0.749 ) is found. We can see that, in our sample, the region where the translators live has no impact on the amount of capital that these professionals say they receive.

\subsubsection{Level of education}

In the questionnaire, subjects were asked to state their highest level of education and 190 subjects answered. One subject did not give an answer while two only stated "other." In view of this, these three subjects were ignored when doing the statistical test.

Level of education was compared using a Spearman's rho correlation coefficient (two-tailed). No correlation is found (correlation coefficient $=0.068, \mathrm{p}=0.350$ ) between the translator's visibility and the translator's level of education. The same testing method was used to compare the translator's level of education with the amount of capital that the subjects said they received. No significant correlation is found (correlation coefficient $=0.101, \mathrm{p}=0.164$ ) between the two variables.

\subsubsection{Major field of study}

In order to examine the relationship between the translator's major field of study and their visibility, we classified our subjects into two groups (translation major and nontranslation major). In our sample, 167 subjects $(86.53 \%)$ stated that they did not major in translation while 19 subjects $(9.84 \%)$ reported that they majored in translation. Seven subjects (3.63\%) did not answer this question. The mean ranks of the translator's visibility are 106.13 for the translation major subjects and 92.06 for the nontranslation major subjects. An independent Mann-Whitney U test (two-tailed) comparing the translator's visibility across these two groups finds no significant difference $(\mathrm{p}=0.275)$.

An independent sample t-test (two-tailed) was performed to study the relationship between the translator's major field of study and the amount of capital that the subjects said they received. The means for the capital received are 2.6435 for the translation major subjects and 2.5705 for the non-translation major subjects. The result of the test shows that there is no significant relationship between the two variables $(\mathrm{p}=0.470)$. 


\subsubsection{Working time}

In the questionnaire, the subjects were asked to indicate how much time they spent on translation-related assignments/activities. A total of 188 subjects answered this question, while five people did not respond. According to the subjects' responses, the mean working time was 23.47 hours per week. The mean working time here is for reference only since non-parametric tests do not rely on the distribution parameters, e.g., mean.

We used a Spearman's rho correlation (two-tailed) to study the relationship between the translator's visibility and their working time. No significant relationship is found (correlation coefficient $=0.044, \mathrm{p}=0.551$ ). The same testing method was used to examine the relationship between the translator's working time and the capital received. No significant relationship is found between the two variables (correlation coefficient $=0.018, \mathrm{p}=0.802$ ).

\subsubsection{The translator's name on the translations}

In the questionnaire, the subjects were asked to indicate if their names appeared on their translations. They were provided with five choices including never, seldom, sometimes, often, and very often. A total of 192 subjects answered, while one subject did not respond. Table 29 shows the number of responses in each category. The response categories were scored as follows: never (0), seldom (1), sometimes (2), often (3), and very often (4). According to the subjects' responses, the mean value is 1.15. Again, the mean value here is for reference only since non-parametric tests do not rely on the distribution parameters, e.g., mean.

TABLE 29

Number of responses in each category concerning the names of translators on their translations

\begin{tabular}{|l|c|}
\hline Response category & Number of subjects \\
\hline Never & 66 \\
\hline Seldom & 60 \\
\hline Sometimes & 48 \\
\hline Often & 8 \\
\hline Very often & 10 \\
\hline Missing & 1 \\
\hline
\end{tabular}

The relationship between the appearance of a translator's name on translations and the translator's visibility was investigated using a Spearman's rho correlation test (two-tailed). A positive moderate relationship is found (the correlation coefficient = $0.262, \mathrm{p}<0.001$ ), indicating that there is a significant relation between the two variables. In other words, the more visible the translators, the more often their names appear on their translations.

Another Spearman's rho correlation test (two-tailed) was performed to examine the relationship between the appearance of a translator's name on translations and the capital that they said they received. A positive strong relationship is found (correlation coefficient $=0.318, \mathrm{p}<0.001$ ), indicating there is a significant relation between the two variables. This implies that the translators whose names appear more often on their translations receive more capital. 


\section{Conclusion and perspectives}

The objective of this paper is to revisit the visibility from the perspective of translators' communicative functions with regard to their clients and end-users. We have adopted an empirical research method to study the relationship between the translator's visibility and the various kinds of capital that these professionals say they receive.

In general terms, our study has found that visibility is rewarding in terms of social exchanges and learning experience, but not in terms of pay and prestige.

Here we would like to emphasize that our analysis is based on 193 Chinese translators in Greater China. Although the sample size is enough upon which to base statistics, the sample size does not represent the vast field in any controlled way. In addition, the technique we adopted is not controlled as we use a convenience sampling method. This may limit the generalizability of findings. Further, our study covers a wide range of translators and therefore the representatives of a particular kind of translator role or professional position might be very few in some cases. Although this study targets Chinese translators in Greater China, our findings are perhaps not specific to Chinese cultural or commercial situations because our questionnaires do not ask about culture-related items and, more importantly, the present quantitative approach is not yet complemented by qualitative interviews.

Having said that, the results of our study do suggest that the more visible the translator, the more capital they receive. Among the four kinds of capital, we have statistically proven that the more visible the translator, the more social and cultural capital they receive. Our findings also reveal that some social variables including sex, level of education, region in which the translator lives, the translator's major field of study, and the number of hours spent working on translation-related assignments are not related to the translator's visibility and the amount of capital received. What is found to be significantly related to the translator's visibility and the capital received is the appearance of a translator's name on translations. As the intention of the present study only focuses on the visibility-capital relationship, we acknowledge other factors such as the translator's personality and cultural variables may also influence either the translator's visibility or the amount of capital received, but these factors are left for future research.

In spite of all the limitations, we believe that our findings have already produced some important insights to invite future investigation into how the subjects judge the importance of the various kinds of capital, i.e., what they want to receive from their work. There are good justifications to embark on such investigations. For example, we can measure the alignment between what the translators wish to receive and what the job allows them to obtain in order to know whether or not the translators are happy with their work. In the literature, very few studies ask whether translators are happy with their work or not. The topic of the translator's job-related happiness is a relatively uncharted area. In the field of translation, client satisfaction is paramount (e.g., Gouadec 2007). Does anyone really care about whether translators are happy with their work and their status? Future investigation into the translator's job-related happiness is worthwhile for as long as we really regard translators as people. 


\section{ACKNOWLEDGMENTS}

This paper presents selected findings from a study which is part of the $\mathrm{PhD}$ research project by the author at the Universitat Rovira i Virgili, Tarragona, Spain (see Liu 2011). I would like to express my sincere gratitude to my supervisors Prof. Anthony Pym and Prof. Leo Chan Tak-hung for invaluable guidance, advice, help and constructive comments on my work.

\section{NOTES}

1. Another article of mine, reporting only on the quantitative analysis of the relationship between translator's visibility and job-related happiness, has been published (Liu 2013). Yet another, on qualitative analysis, will also be published.

2. For a detailed discussion, see my PhD thesis: Liu, Fung-Ming Christy. 2011. A Quantitative and Qualitative Inquiry into Translators' Visibility and Job-related Happiness: The Case of Greater China. Unpublished PhD thesis. Tarragona: Universitat Rovira i Virgili.

3. ProZ.com: Visited in 2009-2010, <http://www.proz.com>.

4. TranslationDirectory.com: Visited in 2009-2010, <http://www.translationdirectory.com> .

5. Ourtra.com: Visited in 2009-2010, <http://www.ourtra.com> .

6. Translators Database [譯者資料庫]: Visited on 15 January 2013, <http://translators-database. blogspot.com>.

7. Facebook is one of the online platforms for recruiting subjects. However, it does not operate in mainland China. Therefore, we recruited participants from Ourtra.com (see note 5), an Internet portal for translators and interpreters in China. Visited in 2009-2010, <https://www.facebook. com>.

\section{REFERENCES}

Angelelli, Claudia (2001): Deconstructing the Invisible Interpreter: A Critical Study of the Interpersonal Role of the Interpreter in a Cross-Cultural/ Linguistic Communicative Event. $\mathrm{PhD}$ thesis, unpublished. California: Stanford University.

Angelelli, Claudia (2004): Revisiting the Interpreter's Role: A Study of Conference, Court, And Medial Interpreters in Canada, Mexico, and the United States. Amsterdam/Philadelphia: John Benjamins.

BAssnett, Susan (2002): Translation Studies. London: Routledge.

Bourdieu, Pierre (1977): Outline of a Theory of Practice. (Translated by Richard NiCE) New York: Cambridge University Press.

Dam, Helle V. and Korning Zethsen, Karen (2008): Translator Status: A Study of Danish Company Translators. The Translator. 14(1):71-96.

Dam, Helle V. and Korning Zethsen, Karen (2009): A study on factors affecting the perception of translator status. Journal of Specialized Translation. 12:2-36.

Gouadec, Daniel (2007): Translation as a Profession. Philadelphia/Amsterdam: John Benjamins.

Hermans, Johan and José Lambert (2006): From translation markets to language management: The implications of translation services In: Dirk Delabastita, Lieven D'hulst, Reine Meylaerts, eds. Functional Approaches to Culture and Translation: Selected Papers by José Lambert. Philadelphia/Amsterdam: John Benjamins, 147-162.

Kiraly, Donald C. (2003): From instruction to collaborative construction. In: Brian James BAER and Geoffrey S. Кову, eds. Beyond the Ivory Tower. Rethinking Translation Pedagogy. Amsterdam/Philadelphia: John Benjamins, 3-28.

Leech, Wendy (2005): The Translator's Visibility: An Investigation into Public Perceptions of the Translator and How to Raise the Translator's Status in Society. MSC thesis, unpublished. London: Imperial College, The University of London.

LIU, Fung-Ming Christy (2011): A Quantitative and Qualitative Inquiry into Translators' Visibility and Job-related Happiness: The Case of Greater China. PhD thesis, unpublished. Tarragona: Universitat Rovira i Virgili. 
Liv, Fung-Ming Christy (2013): A Quantitative Enquiry into the Translator's Job-related Happiness: Does Visibility Correlate with Happiness? Across Languages and Cultures. 14(1):123147.

Risku, Hanna (2004): Migrating from translation to technical communication and usability In: Gyde Hansen, Kirsten Malmkjer and Daniel Gile, eds. Claims, Changes and Challenges in Translation Studies. Amsterdam/Philadelphia: John Benjamins, 181-195.

Sela-Sheffy, Rakefet (2006) The Pursuit of Symbolic Capital by a Semi-Professional Group: The Case of Literary Translators in Israel. In: Michaela WoLF, ed. Übersetzen - Translating Traduire: Towards a "Social Turn"? Münster/Hamburg/Berlin/Wien/London: LIT Verlag, 243-252.

Simeoni, Daniel (1998): The Pivotal Status of the Translator's Habitus. Target. 10(1):1-39.

Sofer, Morry (2006): The Translator's Handbook. Rockville: Schreiber Publishing.

Venuti, Lawrence (1995): The Translator's Invisibility: A History of Translation. London/New York: Routledge.

WARR, Peter (2007): Work, Happiness, and Unhappiness. Mahwah: Lawrence Erlbaum.

WiLss, Wolfram (1999): Translation and Interpreting in the $20^{\text {th }}$ century: Focus on German. Philadelphia/Amsterdam: John Benjamins.

\section{APPENDIX}

\section{Questionnaire*}

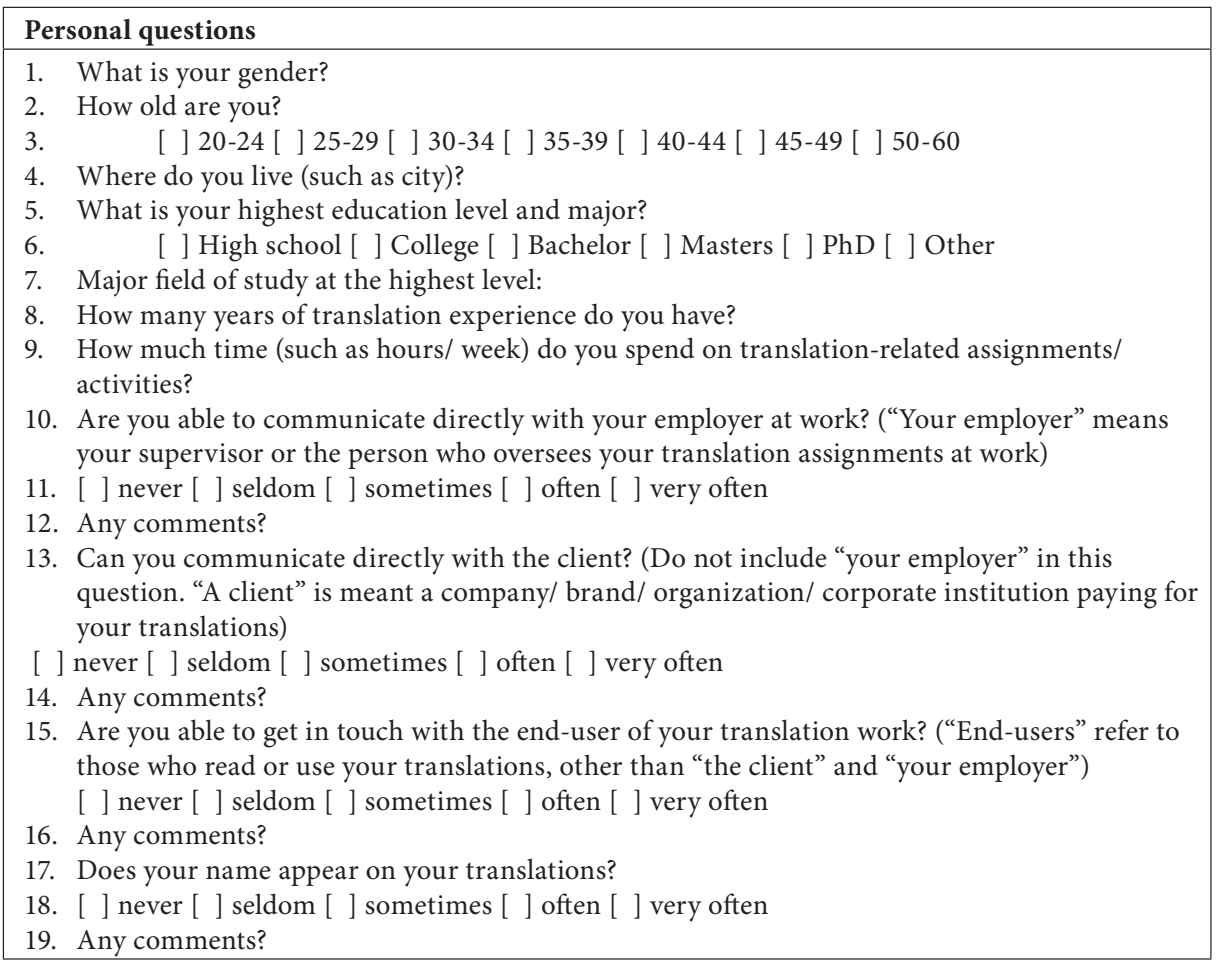




\begin{tabular}{|c|c|c|c|c|c|}
\hline \multicolumn{6}{|c|}{ Please indicate the extent to which you agree or disagree with the following statement: } \\
\hline $\begin{array}{l}\text { SD: Strongly Disagree; D: Disagree; I/NO: Indifferent/No } \\
\text { opinion; A: Agree; SA: Strongly Agree }\end{array}$ & SD & $\mathbf{D}$ & I/ NO & A & SA \\
\hline \multicolumn{6}{|l|}{ I can work independently } \\
\hline \multicolumn{6}{|l|}{ I am allowed to make important decisions at work } \\
\hline \multicolumn{6}{|l|}{ I think I can always meet the client's expectation } \\
\hline \multicolumn{6}{|l|}{ I think I can always meet the end-user's expectation } \\
\hline \multicolumn{6}{|l|}{ My work brings me professional respect } \\
\hline \multicolumn{6}{|l|}{ I feel proud to be a part of the company } \\
\hline \multicolumn{6}{|l|}{$\begin{array}{l}\text { I take pride in my profession. I am proud of being a } \\
\text { translation professional }\end{array}$} \\
\hline \multicolumn{6}{|l|}{ I am treated as a professional translator at work } \\
\hline \multicolumn{6}{|l|}{$\begin{array}{l}\text { I considered myself to be well paid, given the job } \\
\text { responsibilities and performance expectations }\end{array}$} \\
\hline \multicolumn{6}{|l|}{ I believe that the future of my job is secure } \\
\hline \multicolumn{6}{|l|}{ My work brings me valuable personal contacts } \\
\hline \multicolumn{6}{|l|}{$\begin{array}{l}\text { When I do a good job, I receive recognition for it from the } \\
\text { client }\end{array}$} \\
\hline \multicolumn{6}{|l|}{$\begin{array}{l}\text { When I do a good job, I receive recognition for it from the } \\
\text { end-user }\end{array}$} \\
\hline \multicolumn{6}{|l|}{$\begin{array}{l}\text { I can move between roles and I am not limited to doing } \\
\text { translation only }\end{array}$} \\
\hline \multicolumn{6}{|l|}{$\begin{array}{l}\text { I always have the opportunity to work with other translation } \\
\text { professionals }\end{array}$} \\
\hline \multicolumn{6}{|l|}{$\begin{array}{l}\text { I always have the opportunity to work with people from } \\
\text { different professions }\end{array}$} \\
\hline \multicolumn{6}{|l|}{$\begin{array}{l}\text { My work as a translation professional enables me to increase } \\
\text { my knowledge }\end{array}$} \\
\hline \multicolumn{6}{|l|}{ My work enables me to improve my translation skills } \\
\hline \multicolumn{6}{|l|}{ My work boosts my professional qualification } \\
\hline \multicolumn{6}{|l|}{ I can always apply my skills and expertise to my work } \\
\hline \multicolumn{6}{|l|}{$\begin{array}{l}\text { I often receive feedback from the client concerning a text I } \\
\text { have translated }\end{array}$} \\
\hline $\begin{array}{l}\text { I often obtain feedback from the end-user concerning my } \\
\text { work }\end{array}$ & & & & & \\
\hline
\end{tabular}

${ }^{*}$ Note: Questions not analyzed in this paper are not shown. 